\title{
Formaldehyde (HCHO) in air, snow, and interstitial air at Concordia (East Antarctic Plateau) in summer
}

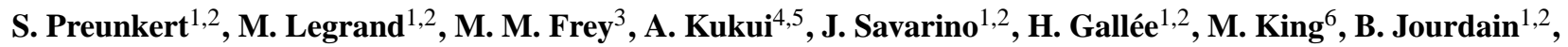 \\ W. Vicars ${ }^{7}$, and D. Helmig ${ }^{7}$ \\ ${ }^{1}$ CNRS, Laboratoire de Glaciologie et Géophysique de l'Environnement (LGGE), 38000 Grenoble, France \\ ${ }^{2}$ Univ. Grenoble Alpes, LGGE, 38000 Grenoble, France \\ ${ }^{3}$ British Antarctic Survey (BAS), Natural Environment Research Council, Cambridge, UK \\ ${ }^{4}$ Laboratoire des Atmosphères, Milieux, Observations Spatiales (LATMOS), Paris, France \\ ${ }^{5}$ Laboratoire de Physique et Chimie de l'Environnement et de l'Espace (LPC2E) UMR-CNRS, Orléans, France \\ ${ }^{6}$ Department of Earth Sciences, Royal Holloway University of London, Egham, Surrey, TW20 0EX, UK \\ ${ }^{7}$ Institute of Arctic and Alpine Research (INSTAAR), University of Colorado, Boulder, USA
}

Correspondence to: S. Preunkert (preunkert@1gge.obs.ujf-grenoble.fr)

Received: 6 November 2014 - Published in Atmos. Chem. Phys. Discuss.: 18 December 2014

Revised: 14 May 2015 - Accepted: 1 June 2015 - Published: 17 June 2015

\begin{abstract}
During the 2011/12 and 2012/13 austral summers, HCHO was investigated for the first time in ambient air, snow, and interstitial air at the Concordia site, located near Dome $\mathrm{C}$ on the East Antarctic Plateau, by deploying an Aerolaser AL-4021 analyzer. Snow emission fluxes were estimated from vertical gradients of mixing ratios observed at $1 \mathrm{~cm}$ and $1 \mathrm{~m}$ above the snow surface as well as in interstitial air a few centimeters below the surface and in air just above the snowpack. Typical flux values range between 1 and $2 \times 10^{12}$ molecules $\mathrm{m}^{-2} \mathrm{~s}^{-1}$ at night and 3 and $5 \times 10^{12}$ molecules $\mathrm{m}^{-2} \mathrm{~s}^{-1}$ at noon. Shading experiments suggest that the photochemical HCHO production in the snowpack at Concordia remains negligible compared to temperature-driven air-snow exchanges. At $1 \mathrm{~m}$ above the snow surface, the observed mean mixing ratio of 130 pptv and its diurnal cycle characterized by a slight decrease around noon are quite well reproduced by 1-D simulations that include snow emissions and gas-phase methane oxidation chemistry. Simulations indicate that the gas-phase production from $\mathrm{CH}_{4}$ oxidation largely contributes $(66 \%)$ to the observed $\mathrm{HCHO}$ mixing ratios. In addition, $\mathrm{HCHO}$ snow emissions account for $\sim 30 \%$ at night and $\sim 10 \%$ at noon to the observed HCHO levels.
\end{abstract}

\section{Introduction}

Over continents, formaldehyde is produced within the atmosphere during the oxidation of numerous hydrocarbons emitted by anthropogenic and natural sources and also directly emitted by combustion. In the remote marine troposphere, HCHO is though to be mainly produced by the photooxidation of $\mathrm{CH}_{4}$, the most abundant atmospheric hydrocarbon (Lowe and Schmidt, 1983). In addition to wet and dry deposition, the main sinks of $\mathrm{HCHO}$ are photolysis and reaction with $\mathrm{OH}$, leading to a typical $\mathrm{HCHO}$ atmospheric lifetime of a few hours (Seinfeld and Pandis, 2006).

At remote high-latitude sites, several studies have been conducted over the Arctic and Antarctic snowpack to evaluate the importance of the snowpack as a formaldehyde source for the atmospheric polar boundary layer (Sumner and Shepson, 1999; Yang et al., 2002; Jacobi et al., 2002; Hutterli et al., 2004; Riedel et al., 1999; Salmon et al., 2008). The understanding of the budget of $\mathrm{HCHO}$ in polar regions is of importance since $\mathrm{HCHO}$ represents an important source of $\mathrm{RO}_{2}$ radicals in the remote polar atmosphere, and is therefore intimately linked to the oxidative capacity of the atmosphere in these regions. This is true in margin regions of Antarctica as concluded on the basis of examinations of the observed $\mathrm{HO}_{x}$ budgets at Halley (Bloss et al., 2007) and Dumont d'Urville (DDU; Kukui et al., 2012). At these two coastal sites, the $\mathrm{HCHO}$ budget was recently discussed by 
Preunkert et al. (2013), who concluded that, depending on the oxidative character of the local atmosphere and the thickness and stability of the atmospheric boundary layer, either the methane oxidation by $\mathrm{OH}$ followed by reaction with $\mathrm{NO}$ or snow emissions from neighboring snow-covered regions dominate the $\mathrm{HCHO}$ budget. At DDU the largest $\mathrm{HCHO}$ source is the methane oxidation in relation to a level of oxidants 3 times higher compared to Halley, and more frequent air mass transport from inland Antarctica there. At Halley, the shallower boundary layer makes snow emissions the dominant HCHO source. The examination of the observed $\mathrm{HO}_{x}$ budget at South Pole (Chen et al., 2004) and Concordia (Kukui et al., 2014) indicated the role of $\mathrm{HCHO}$ on the $\mathrm{RO}_{2}$ budget over the Antarctic Plateau. At South Pole, Hutterli et al. (2004) quantified snow-air fluxes on the basis of both atmospheric vertical gradients and firn air measurements. It should be emphasized here that, to date, South Pole remains the only Antarctic site where such a direct quantification of snow HCHO emissions has been done.

The aims of the present study are (1) to document the boundary layer $\mathrm{HCHO}$ mixing ratio at Concordia during the OPALE (Oxidant Production over Antarctic Land and its Export) project (Preunkert et al., 2012) (see also Kukui et al., 2014), (2) to quantify the summer HCHO snow emissions under conditions encountered at day and night at Concordia, and (3) to compare the role of snow emissions with that of the gas-phase production of $\mathrm{HCHO}$ in central Antarctica.

\section{Methods and field campaigns}

Data presented in this study were obtained during two summer field campaigns that took place at Concordia, located on the high East Antarctic Plateau $\left(75^{\circ} 06^{\prime} \mathrm{S}, 123^{\circ} 33^{\prime} \mathrm{E}\right)$. The 2011/12 campaign, conducted from late November 2011 to mid-January 2012 (i.e., the second OPALE field campaign), was mainly dedicated to documenting $\mathrm{HCHO}$ levels at two different heights in the air above the snow surface and carrying out a few HCHO measurements in interstitial air and in snow. During the 2012/13 campaign (22 December 2012 to 25 January 2013), HCHO was measured at different heights in air and firn in the framework of the snow tower experiment SUNITEDC (Evolution du Sulfate et du Nitrate de l'air et de la neige de Dôme C). Thereby the priority was to gain a detailed picture of the $\mathrm{HCHO}$ distribution in the interstitial air of the snowpack.

In the following section we first describe the analytical method used to measure HCHO. Then, for each campaign, we present the on-site measurement setup and working conditions applied, as well as the detection limits achieved in air, interstitial air, and snow (Sects. 2.2 and 2.3). Finally, the model used to discuss the different source contributions to the atmospheric HCHO budget at Concordia is briefly introduced in Sect. 2.4.

\subsection{Analytical method}

HCHO measurements were performed using a commercial Aerolaser analyzer (AL-4021). The technique, which uses continuous liquid fluorimetry, has been described in detail elsewhere (Dasgupta et al., 1988). Gaseous HCHO is scrubbed into a diluted sulfuric acid solution followed by reaction with the Hantzsch reagent, a dilute mixture of acetyl acetone, acetic acid, and ammonium acetate. Aqueous-phase formaldehyde reacts with the Hantzsch reagent to produce a fluorescent compound that is detected at $510 \mathrm{~nm}$. The working conditions applied to the AL 4021 deployed at Concordia were similar to those applied by Preunkert et al. (2013) in their study conducted at the coastal Antarctic site of Dumont D'Urville. In brief, raw data are monitored with a time resolution of $30 \mathrm{~s}$; gas standard calibration and zero determinations are made every 12 and $2 \mathrm{~h}$, respectively. While Preunkert et al. (2013) used an air flow of 2 L STP $\min ^{-1}$ (leading to a stripping efficiency of $98 \%$ ) to obtain accurate $\mathrm{HCHO}$ measurements of the low winter levels encountered at DDU, the flow rate was set here when possible (see Sect. 2.3) to $1 \mathrm{~L} \mathrm{STP} \min ^{-1}$, as recommended by Aerolaser, to reach a stripping efficiency of more than $99 \%$ (M. Haaks, personal communication, 2011). As discussed by Preunkert et al. (2013), to minimize effects of changing temperatures in the laboratory at Concordia, the monitor was run in a box that was thermostated at $20^{\circ} \mathrm{C}$.

\subsection{The 2011/12 field experiments}

Atmospheric $\mathrm{HCHO}$ was measured at $1 \mathrm{~m}$ (Fig. 1a) and $1 \mathrm{~cm}$ (not shown) above the snow surface at a place located $\sim 900 \mathrm{~m}$ south-southwest from the main station from late November 2011 to mid-January 2012. Two $15 \mathrm{~m}$ long PTFE tubes ( $4 \mathrm{~mm}$ internal diameter) were used to bring ambient air sampled at the two heights into the field laboratory. Air was sucked through the tubes with an external pump at a flow rate of 4 to $6 \mathrm{~L} \mathrm{~min}^{-1}$ to keep its residence time in the lines low enough to keep potential losses below $5 \%$ (see details in Preunkert et al., 2013). To avoid condensation, the air lines were heated. The air inlet of the AL-4021 is connected to either the first or the second of these tubes via a $50 \mathrm{~cm}$ long PTFE tube (internal diameter $4 \mathrm{~mm}$ ) and a PTFEcoated three-way electro valve with an alteration of $15 \mathrm{~min}$. The tightness of the sampling line was regularly controlled. Comparison of the two $15 \mathrm{~m}$ long air lines made by putting their air entries at the same height $(1 \mathrm{~m})$ showed no systematic differences (mean difference of $2.5 \pm 40 \mathrm{pptv}$ over $10 \mathrm{~h}$ ).

The detection limit of the analyzer, calculated as twice the standard deviation of raw data $(30 \mathrm{~s})$ obtained during the 25 min zero measurements, which were made every $2 \mathrm{~h}$, is shown in Fig. 1b. Over the first 2 weeks of the sampling period, the detection limit remained low and similar to what was observed with the same analyzer ( $\sim 30 \mathrm{pptv})$ during the year-round study conducted at DDU by Preunkert et 

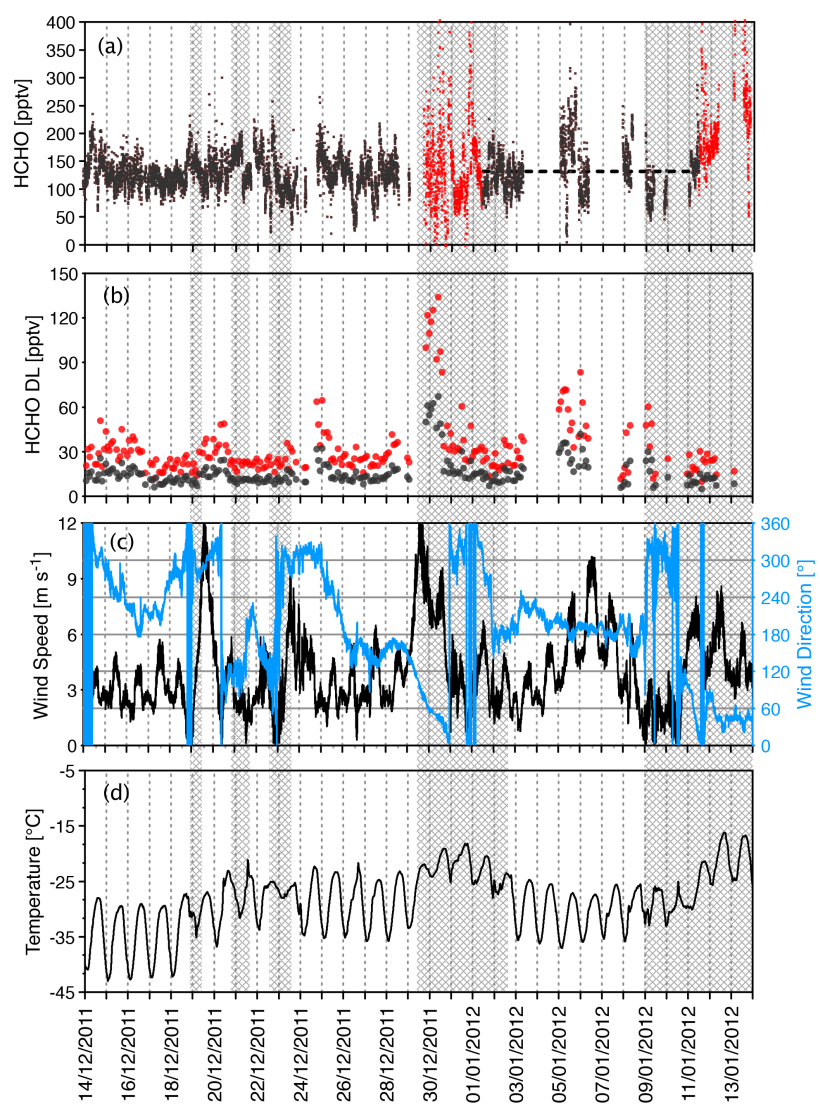

Figure 1. (a) HCHO mixing ratios (time interval of $30 \mathrm{~s}$ ) measured during the 2011/12 OPALE campaign at $1 \mathrm{~m}$ above the snow surface; red points refer to periods during which contamination by wind transport from the station is suspected. The horizontal dashed line indicates the mean mixing ratio observed between 1 and 11 January, a period over which the sampling was very discontinuous. (b) Detection limits (DL), taken as 1 and 2 standard deviations of raw zero values measured every $2 \mathrm{~h}$. (c) Wind speed and direction. (d) Air temperature. Grey bands denote periods during which clouded sky conditions prevailed.

al. (2013). During the second half of the sampling period at Concordia, the detection limit was enhanced, exceeding 100 pptv on 30 December, due to a recurrent presence of air bubbles in the analyzer.

HCHO measurements started on 14 December but were interrupted several times after 3 January due to problems with the fluorimeter of the AL-4021 (see Fig. 1 for data availability). During the sampling period, no significant snowfall event took place and the main wind direction was from the southeast to southwest. However, several episodes (spanning $18 \%$ of the total time) with wind blowing from the north (from the $30^{\circ} \mathrm{W}$ to the $60^{\circ} \mathrm{E}$ sector, i.e., the direction of the station) were encountered (Fig. 1c). Two major north wind periods occurred from 30 December to 1 January in the morning and most of time after 9 January (Fig. 1c). Since scattered $\mathrm{HCHO}$ values were often observed during these events, we cannot exclude a contamination from the station, and therefore the corresponding values were removed from the data set (see red points in Fig. 1a).

Due to either the presence of air bubbles in the analyzer, leading to a detection limit well above $30 \mathrm{pptv}$, or scattered values related to contamination from station activities, qualified data on atmospheric $\mathrm{HCHO}$ at $1 \mathrm{~cm}$ and $1 \mathrm{~m}$ above the snow surface (see Sect. 4) are limited to the period of 14 to 28 December. However, note that the $\mathrm{HCHO}$ mixing ratio at $1 \mathrm{~m}(131 \pm 45 \mathrm{pptv}$ calculated with the few data available between 1 and 11 January; see the horizontal dashed line in Fig. 1a) remains similar to the mean value of $127 \pm 31$ pptv observed between 14 and 28 December.

During the 2011/12 campaign, interstitial air was sampled in the snow between 5 and $100 \mathrm{~cm}$ depth by using a custombuilt firn air probe (a tube of $10 \mathrm{~cm}$ diameter described in Frey et al., 2015) (see Sect. 4.2). The probe was lowered vertically into a pre-cored hole to different snow depths, passing through a disc of $1 \mathrm{~m}$ diameter equipped with a lip of $10 \mathrm{~cm}$, which was resting on the snow surface to limit preferential pumping of ambient air along the tube walls. All probe components were made from UV-transparent Plexiglas. In spite of the firn probe being exposed to Antarctic sunlight over the whole summer of 2009/10, a contamination of up to some $1000 \mathrm{pptv}$ at the beginning of the field season was detected in firn air, coming from the Plexiglas itself and/or from the glue used to assemble the different parts of the probe. In addition, with values of up to a few ppbw (parts per billion by weight), the snow located between the surface and $20 \mathrm{~cm}$ depth around the firn probe was also contaminated. At the end of the season, the contamination of firn air became quasiinsignificant as suggested by the observed $\mathrm{HCHO}$ values at that time $(400 \mathrm{pptv}$ at a depth of $10 \mathrm{~cm})$ that are far lower than those observed at the beginning of the campaign and are in good agreement with those obtained during the 2012/13 campaign. Thus, it was possible to use the device to investigate the influence of UV radiation on $\mathrm{HCHO}$ levels in firn air. This was done 11 January from 10:00 to 18:00 LT by placing UV filters $(2 \times 3 \mathrm{~m}$ sheets of UV-opaque Plexiglas, Acrylite OP-3) at $1 \mathrm{~m}$ above the snow surface. In order to separate radiative and temperature effects, these filters were alternatively exchanged for sheets of UV-transparent Plexiglas (Acrylite OP-4).

Surface snow and snow pit samples were analyzed to document the bulk $\mathrm{HCHO}$ content at Concordia. Twenty meters away from the place where the $\mathrm{HCHO}$ firn measurements were done, the skin layer (the uppermost centimeter) of the snowpack was sampled 6 times on 26 and 27 December, and 26 times from 2 to 4 January. In addition, 20 snow-pit samples were collected down to $70 \mathrm{~cm}$ depth on 27 December. Another snow pit was dug on 9 January at $3 \mathrm{~km}$ from the main station and sampled down to $110 \mathrm{~cm}$ depth $(21 \mathrm{sam}-$ ples). To avoid contamination, samples were collected in airtight Schott glass bottles (Legrand et al., 2007) and analyzed on site within a few hours after sampling. For these measure- 
ments the AL-4021 was run in liquid mode using six liquid standards containing from 0 to 6 ppbw of $\mathrm{HCHO}$, which had been freshly prepared by diluting a certified stock solution of $0.3 \mathrm{gL}^{-1}$ (purchased from the University of Wuppertal, Germany). Under these conditions a detection limit as low as $0.1 \mathrm{ppbw}$ was achieved (Legrand et al., 2007). In addition, snow samples were also analyzed for cations and anions following ion chromatography working conditions reported in Legrand et al. (2013).

\subsection{The 2012/13 field experiments}

HCHO was measured from 22 December 2012 to 25 January 2013 at different heights in air and firn, about $800 \mathrm{~m}$ west from the main station in the clean area sector. During this period no important precipitation occurred and wind never blew from 70 to $110^{\circ} \mathrm{E}$ (i.e., from the direction of the station). Snow temperatures were measured at different depths by using type-E thermocouples (Omega Engineering).

The principle of the snow tower experiment is detailed in Soek et al. (2009) and Helmig et al. (2007). In brief, three towers (one meteorological tower, MT, and two snow towers, ST1 and ST2) were installed in a distance of $\sim 15 \mathrm{~m}$ to sample air above and below the snow surface. In this paper we report HCHO data gained on the MT and ST2. Air was sampled from the MT at around 11,2, and $0.3 \mathrm{~m}$ above the surface at a flow rate of $5 \mathrm{~L} \mathrm{~min}^{-1}$. To avoid collection of ice crystals, each line was equipped with a PFA inlet funnel with $1 \mathrm{~mm}$ grids and $1 \mu \mathrm{m}$ Teflon membrane filters (Savillex Co., USA). On ST2, air is sampled at $20 \mathrm{~cm}$ above the snow surface, just at the surface $(0 \mathrm{~cm})$, and at $20,40,60$, and $80 \mathrm{~cm}$ below the surface. Air was drawn through each paired inlet of ST2 for $10 \mathrm{~min}\left(\right.$ at $\sim 1 \mathrm{~L} \mathrm{~min}^{-1}$ ) every $2 \mathrm{~h}$. Applying the calculations made in Soek et al. (2009) for Dome C conditions, $100 \%$ of sampled interstitial air would correspond to the height of the inlet $\pm 16 \mathrm{~cm}$, and $66 \%$ to the height of the inlet $\pm 7 \mathrm{~cm}$. This avoids significant overlapping with the adjacent inlets. For a given depth, the time between two subsequent samplings $(2 \mathrm{~h})$ is more than twice the time needed for air under Dome $\mathrm{C}$ conditions to re-equilibrate to its original conditions (see calculations made in Soek et al., 2009). Twenty-five millimeter Acrodisc hydrophobic PTFE syringe filters (Pall Life Sciences) previously passivized with $\mathrm{O}_{3}$ were placed at all ST inlets to protect them from ice crystals.

During the campaign, sampled air was provided to the AL4021 and to each of the other running analyzers $\left(\mathrm{NO}_{x}, \mathrm{Hg}\right.$, and $\mathrm{CO}$; not discussed here), with a flow rate of $1 \mathrm{~L} \mathrm{~min}^{-1}$ (i.e., $0.7 \mathrm{~L} \mathrm{STP} \mathrm{min}^{-1}$ ). Therefore, the airflow of the AL4021 was set to $0.6 \mathrm{~L} \mathrm{STP} \mathrm{min}^{-1}$, which is $40 \%$ lower than that normally applied for the AL-4021 (see Sect. 2.1), resulting in an $\sim 25 \%$ lower sensibility of the instrument. Taken as twice the standard deviation of zero measurements, the detection limit was $67 \pm 22$ pptv from 22 December to 6 January (151 zero measurements) and $120 \pm 55$ pptv from 6 to 25 January (185 zero measurements). These rather high de-
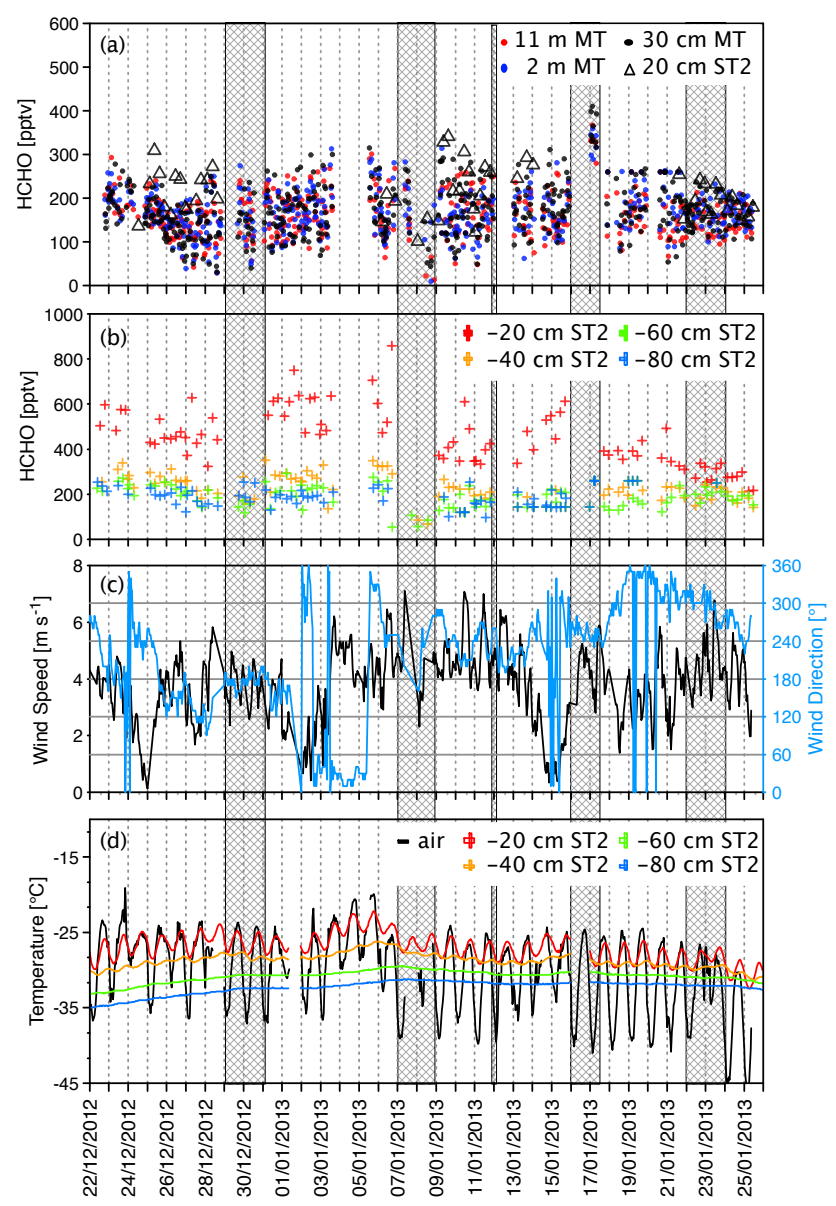

Figure 2. (a) Ten-minute averaged HCHO mixing ratios observed in the ambient air during the 2012/13 campaign at three different heights above the snow on the meteorological tower (MT) and at $20 \mathrm{~cm}$ on snow tower 2 (ST2) (see Sect. 2.3). (b) Ten-minute averaged HCHO measured at different depths in the snowpack on ST2. (c) Wind speed and direction. (d) Temperature of air and in snow at different depths (ST2). Grey bands denote periods for which data were not considered due to technical problems with the analyzer and/or the snow tower system. They separate the six time intervals over which data were averaged.

tection limits were related to a more frequent presence of air bubbles in the analyzer lines than it was observed in other experiments performed with the device (see Sect. 2.2). Twice per week, the inlets of the three MT lines were placed for $1 \mathrm{~h}$ at $2 \mathrm{~m}$ height, showing no systematic differences $(4 \pm 21$ and $5 \pm 29$ pptv with respect to one inlet reference). Such a comparison of the different air lines was not possible for ST2 since HCHO measurements started well after they had been set up in snow.

As can be seen in Fig. 2a, overall means of HCHO air mixing ratios measured at MT through the 11,2 , and $0.3 \mathrm{~m}$ inlets are $164 \pm 55,168 \pm 54$, and $170 \pm 61 \mathrm{pptv}$, respectively. The mean value observed at $20 \mathrm{~cm}$ above the snow surface at ST2 is $203 \pm 55$ pptv. From 20 to 22 December, HCHO was sam- 
Table 1. Gas-phase reactions included in the 1-D model (see Sect. 2.4). Kinetic rates are given in $\mathrm{cm}^{3} \mathrm{molecules}^{-1} \mathrm{~s}^{-1}$. HCHO and MHP $\left(\mathrm{CH}_{3} \mathrm{OOH}\right)$ photolysis rates are shown in Fig. 8.

\begin{tabular}{|c|c|c|c|}
\hline No. & Reactions & Kinetic rates & References \\
\hline 1 & $\mathrm{CH}_{4}+\mathrm{OH}+\mathrm{O}_{2} \rightarrow \mathrm{CH}_{3} \mathrm{O}_{2}+\mathrm{H}_{2} \mathrm{O}$ & $2.45 \times 10^{-12} \exp [-1775 / T]$ & DeMore et al. (1997) \\
\hline 2 & $\mathrm{CH}_{3} \mathrm{O}_{2}+\mathrm{NO} \rightarrow \mathrm{CH}_{3} \mathrm{O}+\mathrm{NO}_{2}$ & $2.30 \times 10^{-12} \exp [360 / T]$ & Atkinson et al. (2006) \\
\hline 3 & $\mathrm{CH}_{3} \mathrm{O}+\mathrm{O}_{2} \rightarrow \mathrm{HCHO}+\mathrm{HO}_{2}$ & $7.20 \times 10^{-14} \exp [-1080 / T]$ & Atkinson et al. (2006) \\
\hline 4 & $\mathrm{CH}_{3} \mathrm{O}_{2}+\mathrm{CH}_{3} \mathrm{O}_{2} \rightarrow 2 \mathrm{CH}_{3} \mathrm{O}+\mathrm{O}_{2}$ & $\begin{array}{l}\left(7.40 \times 10^{-13} \exp [-520 / T]\right. \\
\left.-1.03 \times 10^{-13} \exp [800 / T]\right) 0.35\end{array}$ & Atkinson et al. (2006) \\
\hline 5 & $\mathrm{CH}_{3} \mathrm{O}_{2}+\mathrm{CH}_{3} \mathrm{O}_{2} \rightarrow \mathrm{CH}_{3} \mathrm{OH}+\mathrm{HCHO}+\mathrm{O}_{2}$ & $\left(1.03 \times 10^{-13} \exp [800 / T]\right) 0.65$ & Atkinson et al. (2006) \\
\hline 6 & $\mathrm{CH}_{3} \mathrm{O}_{2}+\mathrm{HO}_{2} \rightarrow \mathrm{CH}_{3} \mathrm{OOH}+\mathrm{O}_{2}$ & $3.80 \times 10^{-13} \exp [780 / T]$ & Atkinson et al. (2006) \\
\hline 7 & $\mathrm{CH}_{3} \mathrm{OOH}+\mathrm{OH} \rightarrow \mathrm{HCHO}+\mathrm{HO}+\mathrm{H}_{2} \mathrm{O}$ & $\left(2.93 \times 10^{-12} \exp [190 / T]\right) 0.35$ & Atkinson et al. (2006) \\
\hline 8 & $\mathrm{CH}_{3} \mathrm{OOH}+\mathrm{OH} \rightarrow \mathrm{CH}_{3} \mathrm{O}_{2}+\mathrm{H}_{2} \mathrm{O}$ & $\left(1.78 \times 10^{-12} \exp [220 / T]\right) 0.65$ & Atkinson et al. (2006) \\
\hline 9 & $\mathrm{HCHO}+\mathrm{OH} \rightarrow \mathrm{H}_{2} \mathrm{O}+\mathrm{HCO}$ & $5.40 \times 10^{-12} \exp [135 / T]$ & Atkinson et al. (2006) \\
\hline 10 & $\mathrm{CH}_{3} \mathrm{OOH} \rightarrow \mathrm{CH}_{3} \mathrm{O}+\mathrm{OH}(\lambda<645 \mathrm{~nm})$ & $J_{\mathrm{MHP}}$ & \\
\hline 11 & $\mathrm{HCHO} \rightarrow \mathrm{H}_{2}+\mathrm{CO}(\lambda<337 \mathrm{~nm})$ & $J_{\mathrm{HCHO}-\mathrm{mol}}$ & \\
\hline 12 & $\mathrm{HCHO} \rightarrow \mathrm{H}+\mathrm{HCO}(\lambda<360 \mathrm{~nm})$ & $J_{\mathrm{HCHO}-\mathrm{rad}}$ & \\
\hline 13 & $\mathrm{Br}+\mathrm{HCHO} \rightarrow \mathrm{HBr}+\mathrm{HCO}$ & $2.7 \times 10^{-12} \exp [-580 / T]$ & Atkinson et al. (2007) \\
\hline 14 & $\mathrm{BrO}+\mathrm{CH}_{3} \mathrm{O}_{2} \rightarrow \mathrm{CH}_{2} \mathrm{O}_{2}+\mathrm{HOBr}$ & $5.70 \times 10^{-12}$ & Atkinson et al. (2008) \\
\hline 15 & $\mathrm{BrO}+\mathrm{HCHO} \rightarrow \mathrm{HOBr}+\mathrm{HCO}$ & $1.50 \times 10^{-14}$ & Michalowski et al. (2000) \\
\hline
\end{tabular}

pled at $20 \mathrm{~cm}$ above the surface by using a $3 \mathrm{~m}$ long PTFE line (internal diameter $4 \mathrm{~mm}$ ) connected directly to the AL4021 , giving a mixing ratio of $135 \pm 48 \mathrm{pptv}$. In view of the high variability encountered for $\mathrm{HCHO}$ measurements during this experiment, these values show no significant difference. However, the relative high mean atmospheric $\mathrm{HCHO}$ mixing ratios measured at ST2 might also be related to the fact that ST air lines were not flushed continuously but only for $10 \mathrm{~min}$ every $2 \mathrm{~h}$. Given these enhanced measurement uncertainties, absolute atmospheric $\mathrm{HCHO}$ mixing ratios are not investigated within this 2012/13 data set, but the measurements will be used to examine HCHO in interstitial air (see Sect. 4.2), with a view of deriving $\mathrm{HCHO}$ fluxes between the snowpack and the atmosphere (Sect. 5.2) and discussing its firn-air equilibrium (Sect. 5.3).

\subsection{Model calculations}

Observed HCHO mixing ratios (daily mean and diurnal variation) were compared with those simulated by a 1-D box model that considers snow HCHO emissions as well as the local gas-phase photochemistry.

Input parameters used in the model were gained from onsite atmospheric measurements made during the 2011/12 experiment, including $\mathrm{NO}, \mathrm{OH}, \mathrm{RO}_{2}$, and methyl hydroperoxide (MHP). NO was determined with a two-channel chemiluminescence detector following working conditions detailed in Frey et al. $(2013,2015)$. The $\mathrm{OH}$ and $\mathrm{RO}_{2}$ radicals were measured using chemical ionization mass spectrometry (Kukui et al., 2012, 2014). During the campaign the photolysis rates of $\mathrm{HCHO}$ were documented using a $2 \pi$ spectroradiometer (Metcon). MHP was measured together with $\mathrm{H}_{2} \mathrm{O}_{2}$ by deploying an Aerolaser AL-2021 instrument as during the first OPALE campaign conducted at DDU (Preunkert et al., 2012).

For snow emissions, we used values derived from the observed vertical gradient between $1 \mathrm{~cm}$ and $1 \mathrm{~m}$ above the snow surface as well as those derived from the observed difference between snow interstitial air and air above the snow surface (see Sect. 5). For calculations of the gas-phase photochemistry we considered the model used by Preunkert et al. (2013) to examine the budget of HCHO at the Antarctic coast including the $\mathrm{CH}_{4}$ oxidation as well as the oxidation of non-methane hydrocarbons (light alkenes and dimethyl sulfide (DMS)) together with major sinks of HCHO (its photolysis and reaction with $\mathrm{OH}$ ). For simulations at Concordia, we neglected the oxidation of ethene and DMS oxidation pathways. Indeed, even with a DMS summer mixing ratio of 50 pptv at DDU (compared to less than 1 pptv at Concordia; Preunkert et al., 2008), and an ethene level of $17 \mathrm{pptv}$ (compared to less than 3 pptv expected for Concordia as measured at South Pole; Beyersdorf et al., 2010), Preunkert et al. (2013) concluded that the gas-phase production of HCHO from DMS and non-methane hydrocarbons only represents a few percent of the gas-phase production (i.e., $\sim 4 \%$ ) dominated by the methane oxidation. The 15 gas-phase reactions considered in this work (see Table 1) will also allow for the influence of the bromine chemistry to be evaluated.

The vertical transport of the 1-D model was represented using vertical distribution of turbulent diffusion coefficients $\left(K_{z}\right)$ calculated by the regional atmospheric model MAR (Modèle Atmosphérique Régional). More details on MAR and its reliability at Concordia during the OPALE campaign are given in Gallée and Gorodetskaya (2008) and Gallée et 
Table 2. Atmospheric HCHO mixing ratios in the lower Antarctic atmosphere.

\begin{tabular}{lllll}
\hline Site & Date & HCHO (pptv) & Location & References \\
\hline South Pole & Dec 2000 & 103 & $89.98^{\circ} \mathrm{S}, 24.8^{\circ} \mathrm{W}$ & Hutterli et al. (2004) \\
South Pole & 2-4 Jan 2003 & 155 & $89.91^{\circ} \mathrm{S}, 147.57^{\circ} \mathrm{W}$ & Frey et al. (2005) \\
Byrd & 28 Nov 2011-11 Dec 2002 & $120 \pm 50$ & $80.02^{\circ} \mathrm{S}, 119.6^{\circ} \mathrm{W}$ & Frey et al. (2005) \\
Halley & Dec 2004-Jan 2005 & $90-140$ & $75.58^{\circ} \mathrm{S}, 26.65^{\circ} \mathrm{W}$ & Salmon et al. (2008) \\
DDU & Jan 2009 and Dec 2009 & $150-195$ & $66.66^{\circ} \mathrm{S}, 140.02^{\circ} \mathrm{E}$ & Preunkert et al. (2013) \\
Concordia & 14 Dec 2011-11 Jan 2012 & $130 \pm 37$ & $75.1^{\circ} \mathrm{S}, 123.55^{\circ} \mathrm{E}$ & This study \\
\hline
\end{tabular}

al. (2015). Similar to calculations performed by Legrand et al. (2014), we used the MAR data obtained with a horizontal resolution of $20 \mathrm{~km}$ centered at Concordia, and a vertical resolution of $0.9 \mathrm{~m}$ for the height of up to $23 \mathrm{~m}$ above the surface, decreasing upward to about $50 \mathrm{~m}$ at the height of $500 \mathrm{~m}$ and to $\sim 1800 \mathrm{~m}$ at the top level of $\sim 24 \mathrm{~km}$. For the 1-D model, the $K_{z}$ values were linearly interpolated to the vertical 1-D grid, which was $0.1 \mathrm{~m}$ from the surface to $5 \mathrm{~m}$, $0.2 \mathrm{~m}$ from 5 to $7 \mathrm{~m}, 0.5 \mathrm{~m}$ from 7 to $10 \mathrm{~m}$, around $1 \mathrm{~m}$ from 10 to $20 \mathrm{~m}$, and then increased up to 120 at $1200 \mathrm{~m}$, the top height of the 1-D model. Note that the planetary boundary layer (PBL) height, defined by MAR as the height where the turbulent kinetic energy decreases below the value at the lowest layer of the model, was always lower than the top layer of the 1-D model during the OPALE campaign.

Since cloud cover is responsible for an increase of around $50 \%$ of the downwelling long-wave radiation in summer at Dome $\mathrm{C}$, but MAR underestimates cloud cover, the surface heat budget is not well simulated during overcast days, and this strongly impacts the turbulence simulated by the model. We therefore performed calculations only for days with clear-sky conditions.

\section{Ambient air HCHO mixing ratio at Concordia in summer 2011/12}

At Concordia, atmospheric $\mathrm{HCHO}$ levels remained close to $130 \pm 37 \mathrm{pptv}$ from mid-December 2011 to midJanuary 2012. Though underlying an enhanced variability, atmospheric HCHO mixing ratios measured from midDecember 2012 to end of January 2013 (see Sect. 2.3) also seem to be free of important fluctuations. These quite constant $\mathrm{HCHO}$ mixing ratios contrast with observations made at South Pole, where fast $\mathrm{HCHO}$ decreases were observed during fog events (up to 100 pptv; Hutterli et al., 2004). At Concordia, the regular appearance of diamond dusts during early morning does not seem to disturb the daily course of the HCHO level (Fig. 3).

The HCHO level of 130 pptv observed at Concordia is consistent with those levels observed by Frey et al. (2005) at South Pole and Byrd (Table 2). For South Pole, the mean value reported for 16 days by Hutterli et al. (2004) is lower than the one observed by Frey et al. (2005) over 3 days
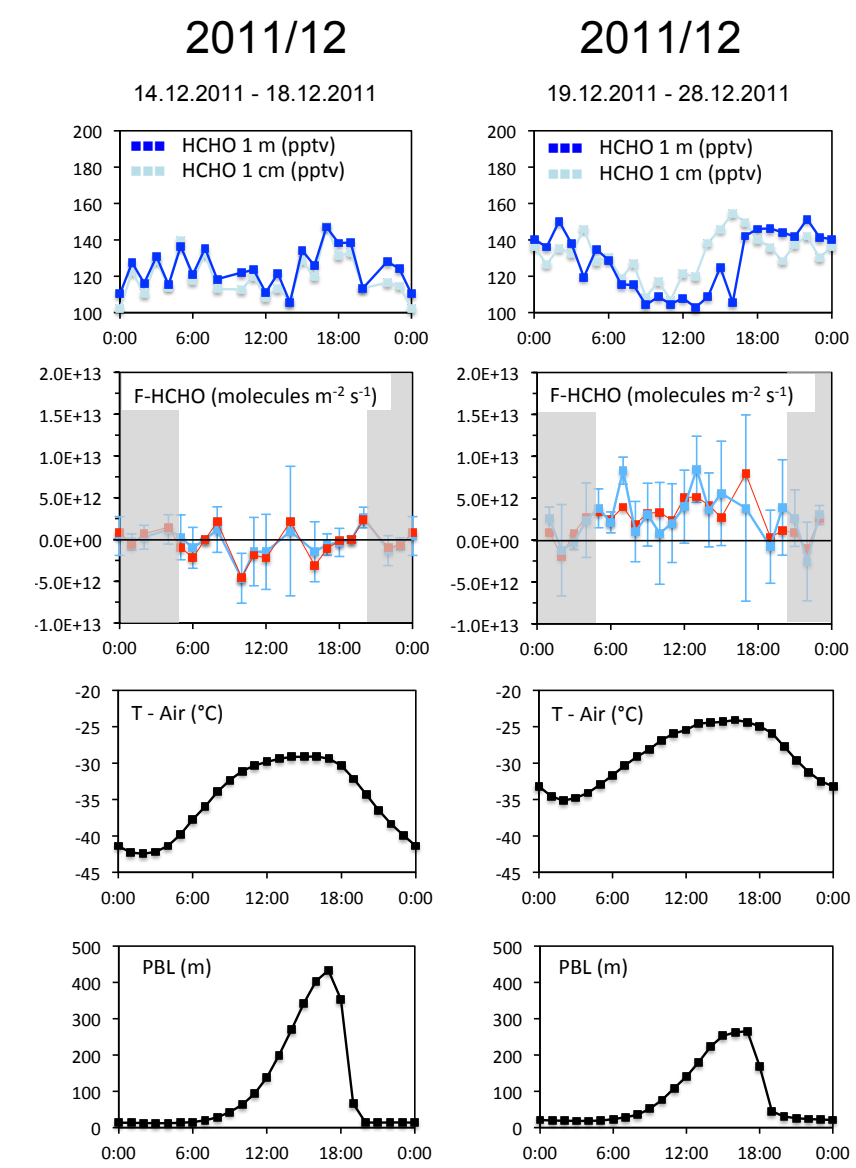

Figure 3. From top to bottom: mean daily course (hours are LT) of $\mathrm{HCHO}$ mixing ratios measured at $1 \mathrm{~m}$ and $1 \mathrm{~cm}$ above the ground, snow to air fluxes calculated from observed vertical gradients between $1 \mathrm{~m}$ and $1 \mathrm{~cm}$ (arithmetic means in blue; median values in red), measured ambient air temperatures at Concordia, and simulated PBL heights.

(103 pptv compared to $155 \mathrm{pptv}$ ). However, during the period covered by measurements, Hutterli et al. (2004) experienced 3 days with values close to $50 \mathrm{pptv}$, corresponding to fog events that depleted HCHO in the boundary layer. Discarding these 3 days a mean value of 111-115 pptv is calculated. Note also that these values observed in inland Antarctica remain on the same order as the ones reported at the coast 
(Table 2), for which Preunkert et al. (2013) discussed major sources (methane oxidation and snow emissions) and sinks (photolysis, destruction by $\mathrm{OH}$, and dry deposition). The contribution of these different processes on the atmospheric HCHO budget at Concordia will be quantified in Sect. 6 .

The daily course of atmospheric $\mathrm{HCHO}$ mixing ratios is shown in Fig. 3. Here we removed data gained during overcast weather (see Fig. 1) to make the data consistent with simulations made in Sect. 6 since the PBL height from MAR is significantly improved under clear-sky conditions. We have examined separately data gained over two periods (from 14 to 18 and 19 to 28 December) in view of the significant rise of the temperature between 18 and 19 December (Fig. 1d). In spite of this change in temperature, the mean $\mathrm{HCHO}$ mixing ratios remained similar over the two periods (124 pptv from 14 to 18 December and 128 pptv from 19 to 28 December). Since enhanced temperatures are expected to increase HCHO snow emissions (Hutterli et al., 2002; Barret et al., 2011a), and given the decrease in the PBL height between the time before 19 December and thereafter, rather unchanged HCHO mixing ratios would suggest that snow emissions only weakly control the $\mathrm{HCHO}$ budget of the atmospheric boundary layer at Concordia. This point will be further discussed in Sect. 6.

From 14 to 18 December, only a small day-night difference of $\mathrm{HCHO}$ values can be observed with slightly lower daytime values (116 pptv between 08:00 and 14:00 LT) than nighttime values (126 pptv between 15:00 and 07:00 LT). During the following period (19 to 28 December), when air temperatures were enhanced, a marked daily cycle (amplitude close to $30 \mathrm{pptv}$ ) characterized by a broad minimum from 07:00 to 15:00 LT and a broad maximum from 16:00 to $06: 00 \mathrm{LT}$ is observed.

\section{HCHO in the snowpack}

\subsection{HCHO in snow}

Figure 4a shows the bulk snow HCHO profiles obtained in the two snow pits dug at Concordia during the 2011/12 campaign (Sect. 2.2). The good agreement of data between the snow pit dug 27 December near the air sampling site and the 9 January one dug at $3 \mathrm{~km}$ from the station suggests that station activities had little impact on the $\mathrm{HCHO}$ content of the snowpack in the immediate vicinity of the station. Note that the two profiles are also in good agreement with the profile made by Hutterli et al. (2002) in January 1998 (i.e., well before the start in 2003 of overwintering station activities at Concordia).

The three depth profiles show a similar decreasing trend with depth, reaching a value of $0.2-0.3$ ppbw below $70 \mathrm{~cm}$ depth. Some differences exist between the three profiles with a maximum of 1 ppbw measured by Hutterli et al. (2002) at the surface compared to lower values in this study. In- (a)

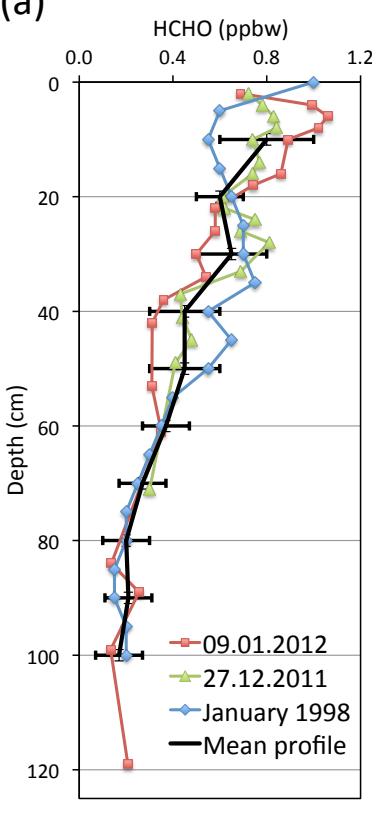

(b)
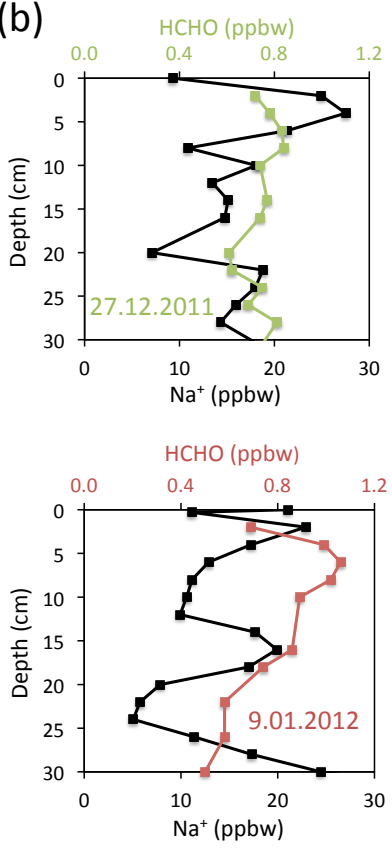

Figure 4. (a) Vertical profiles of $\mathrm{HCHO}$ in bulk snow at Concordia. The vertical snow profiles of HCHO obtained from the two snow pits dug during the 2011/12 campaign are compared to those from a snow pit dug in January 1998 (Hutterli et al., 2002). (b) Sodium versus $\mathrm{HCHO}$ content in the upper $30 \mathrm{~cm}$ of the two snow pits dug in $2011 / 12$.

deed, with individual values ranging from 0.2 to $0.4 \mathrm{ppbw}$, the 26 skin layer snow samples (Sect. 2.2) show mean levels $(0.27 \pm 0.05 \mathrm{ppbw}$ from 26 to 27 December and $0.29 \pm 0.07$ ppbw from 2 to 4 January) that are well below the maximum seen in the snow-pit profiles $(0.8 \mathrm{ppbw}$ at $8 \mathrm{~cm}$ depth for the 27 December pit and 1.0-1.2 ppb between 5 and $15 \mathrm{~cm}$ depth in the 9 January pit). Such a large variability in the HCHO mixing ratios in the uppermost snow layers was often reported in previous studies conducted at other polar sites. It has been suggested that this is due to the presence or absence of freshly deposited snow, which is always more enriched in $\mathrm{HCHO}$ with respect to atmospheric mixing ratios than aged snow layers (Hutterli et al., 1999, 2002, 2004). Under Concordia conditions, as discussed in Sect. 4.3, snow in equilibrium with the atmosphere in summer would contain at least 2.6 ppbw of $\mathrm{HCHO}$.

In the 9 January snow pit, the maximum of HCHO mixing ratios seen from 5 to $15 \mathrm{~cm}$ below the surface (Fig. $4 \mathrm{~b}$ ) coincides with two relative maxima of sodium, suggesting that they correspond to winter snow layers. Given the typical snow accumulation of $10 \mathrm{~cm}$ of snow at Concordia, these two depths correspond to winter 2011 and winter 2010. For the 27 December snow pit, the wide maximum of HCHO still coincides with these two winter layers seen in the corresponding sodium profile. The HCHO profile obtained by Hutterli et al. (2002) is more flat with a less variable value between 5 
and $25 \mathrm{~cm}$ below the surface. In the absence of sodium data in this previous study, it remains difficult to conclude whether that is due to a strong wind-driven redistribution of summer and winter snow layers by the wind at the snow pit location sampled by Hutterli et al. (2002) in 1998.

HCHO snow-pit profiles are also available from South Pole (Hutterli et al., 2004) and Summit Station in central Greenland (Hutterli et al., 1999). At both sites, winter HCHO maxima close to $\sim 4-6$ ppbw were observed. Deeper in the snow at $1.6 \mathrm{~m}$ depth, concentrations decrease to a nearly constant level of 4 ppbw at Summit and 0.3-1.1 ppbw at South Pole. The higher concentration observed in deeper snow layers at Summit than at South Pole was suggested to be driven by the fact that the mean snow accumulation rate is higher at Summit $\left(22 \mathrm{~g} \mathrm{H}_{2} \mathrm{O} \mathrm{cm}^{-2} \mathrm{yr}^{-1}\right)$ than at South Pole (6$11 \mathrm{~g} \mathrm{H}_{2} \mathrm{O} \mathrm{cm}^{-2} \mathrm{yr}^{-1}$ ) (Hutterli et al., 2002). The larger snow accumulation at Summit permits better preservation of the atmospheric signal that dominates the weaker uptake capacity of $\mathrm{HCHO}$ in snow and ice at warmer temperatures (Burkhart et al., 2002; Barret et al., 2011a) at Summit compared to South Pole (mean annual $T$ of $-31{ }^{\circ} \mathrm{C}$ compared to $-49^{\circ} \mathrm{C}$ at South Pole). Thus, considering the quite similar temperatures at Concordia and South Pole (mean annual $T$ of $-54{ }^{\circ} \mathrm{C}$ compared to $-49^{\circ} \mathrm{C}$ at South Pole), the lower mean snow accumulation $\left(2.8 \mathrm{~g} \mathrm{H}_{2} \mathrm{O} \mathrm{cm}^{-2} \mathrm{yr}^{-1}\right.$ compared to $6-11 \mathrm{~g} \mathrm{H}_{2} \mathrm{O} \mathrm{cm}^{-2} \mathrm{yr}^{-1}$ at South Pole) may reduce the preservation there, explaining the lower content in deep snow layers at Concordia than at South Pole.

\subsection{HCHO in interstitial air}

During both the 2011/12 and 2012/13 field campaigns, investigations were made to document $\mathrm{HCHO}$ in the interstitial firn air (Fig. 5). The mean value observed at $20 \mathrm{~cm}$ depth in $2012 / 13$ (530 \pm 95 pptv) largely exceeds the one in the atmosphere ( $\sim 130$ pptv observed in $2011 / 12$ and $135-170$ pptv observed in 2012/13). Similar enhancements of HCHO in firn air have been seen in a previous study conducted at South Pole (750 pptv at $10 \mathrm{~cm}$ depth compared to $103 \mathrm{pptv}$ in the atmosphere; Hutterli et al., 2004). Figures 4 and 5 show that, similar to the HCHO profile in snow, firn air HCHO levels show highest values near the snow surface and decreasing levels with depth, reaching values lower than 100 pptv below $80 \mathrm{~cm}$ depth. Whereas the data presented here of the HCHO change with depth in firn air are unique for Antarctica (no depth profile of interstitial air content is available from South Pole), a similar depth profile was reported for Summit by Hutterli et al. (1999), with 1500-2000 pptv at 5-20 cm below the snow surface (compared to 230 pptv in the atmosphere) and $400 \mathrm{pptv}$ at $1.5 \mathrm{~m}$ below the surface. The elevated mixing ratios in the firn air at Concordia with respect to those in the atmosphere indicate the snowpack as a source of $\mathrm{HCHO}$ for the atmosphere in summer.

As can be seen in Fig. 6, HCHO mixing ratios measured at $-20 \mathrm{~cm}$ in firn air coincide more closely with the daily

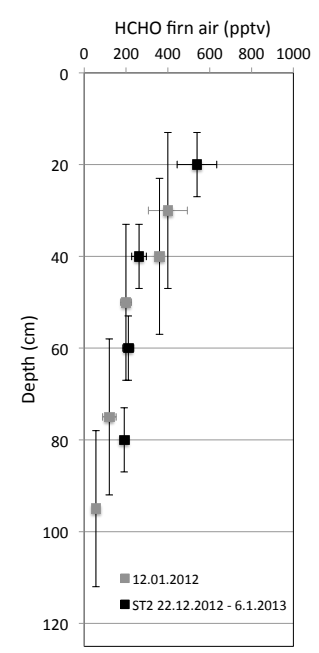

Figure 5. Vertical profiles of HCHO in interstitial air at Concordia. Vertical bars refer to the depth from which $66 \%$ of air was sampled (see Sect. 2.3) and the horizontal ones to standard deviations of $10 \mathrm{~min}$ and $30 \mathrm{~s}$ means for $2012 / 13$ and 2011/12, respectively.

course of temperature measured above the surface and at $-20 \mathrm{~cm}$ than with the daily course of irradiance peaking at noon. Thus, the temperature variation in the uppermost snow layers should drive the HCHO firn air mixing ratios there, which tend to increase at warmer temperatures. In addition, during the first week of January, the daily mean HCHO mixing ratio at $-20 \mathrm{~cm}(600 \mathrm{pptv})$ was higher than the one after 9 January (400 pptv) in relation to a decrease in the temperature, from -27.5 to $-31.3^{\circ} \mathrm{C}$. This dependence of $\mathrm{HCHO}$ firn air in the upper snowpack will be discussed further in the next section.

\subsection{The firn air-snow partitioning at Concordia}

\subsubsection{The HCHO-ice thermodynamic equilibrium}

On the basis of laboratory experiments, two studies have investigated the HCHO partitioning between air and ice. The first attempt was made by Burkhart et al. (2002), who conducted laboratory experiments with pure ice between -5 and $-35^{\circ} \mathrm{C}$. However, they emphasized that the duration of laboratory experiments (less than 2 days) was not long enough to permit the ice to reach equilibrium, in particular at $-35^{\circ} \mathrm{C}$. In a more recent study, Barret et al. (2011a) measured the solubility and the diffusivity of $\mathrm{HCHO}$ in ice between -7 and $-30^{\circ} \mathrm{C}$, showing that the partitioning of $\mathrm{HCHO}$ between snow and atmosphere can be described by $K(T)=$ $X_{\mathrm{HCHO}} /\left(P_{\mathrm{HCHO}}\right)^{0.803}$ (with $X_{\mathrm{HCHO}}$ being the $\mathrm{HCHO}$ molar fraction, $P_{\mathrm{HCHO}}$ being in pascal, and $T$ being in kelvin), in which $K(T)$ follows an Arrhenius law. This equilibrium law is shown in Fig. 7 (black solid line) along with the one (black dashed line) from Burkhart et al. (2002), the large difference between the two derived laws at low temperatures clearly re- 

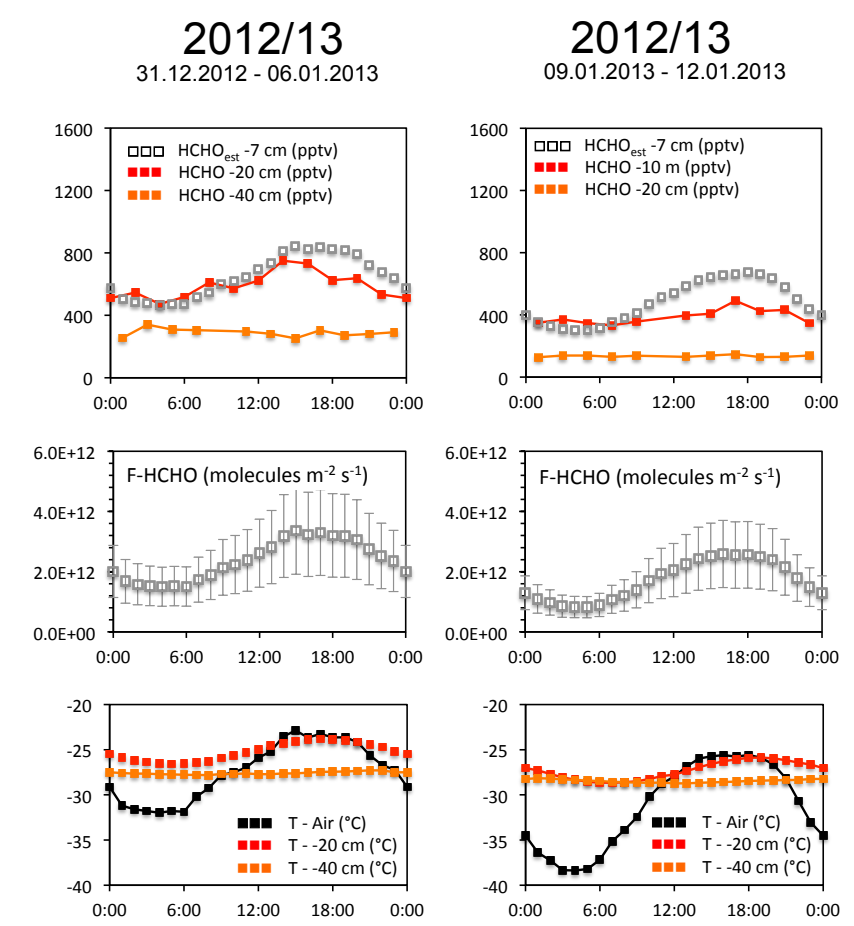

Figure 6. Top: mean daily course (hours are LT) of firn air HCHO mixing ratios at different depths. At $7 \mathrm{~cm}$ below the snow surface, $\mathrm{HCHO}$ mixing ratios were estimated. Second from top: $\mathrm{HCHO}$ flux calculated from firn air atmosphere gradients. Error bars refer to uncertainties in depth $( \pm 3 \mathrm{~cm})$ and in snow concentration $( \pm 0.08 \mathrm{ppbw})$ (see text in Sect. 3.3). Bottom: air and firn air temperatures.

veals the undersaturation of the ice in the experiments conducted by Burkhart et al. (2002).

A few studies have attempted to compare the partitioning of $\mathrm{HCHO}$ between air and snow observed during field campaigns with the thermodynamic equilibrium obtained in laboratory studies. This was done by Burkhart et al. (2002) with bulk snow and firn air data obtained by Hutterli et al. (1999) in a $3 \mathrm{~m}$ snow pit dug at Summit. Barret et al. (2011b) examined whether the Alaskan Arctic snowpack follows the thermodynamic equilibrium. However, it should be emphasized here that, in this latter study, air concentrations were not measured in the snowpack and were assumed to be identical to those measured $60 \mathrm{~cm}$ above the surface snow (see discussions below). Even more limited were examinations of the $\mathrm{HCHO}$ partitioning between air and snow in Antarctica, as firn air measurements are very rarely available there. Hutterli et al. (2004) performed a few firn air measurements at $10 \mathrm{~cm}$ below the surface at South Pole in December 2000. These previous data (Summit, Barrow, and South Pole) are shown in Fig. 7 together with those gained in this study at Concordia. Due to the existence of a residual diurnal temperature cycle at $20 \mathrm{~cm}$ below the surface (see Fig. 6), data from this depth are shown in Fig. 7 as 10 min means, while those

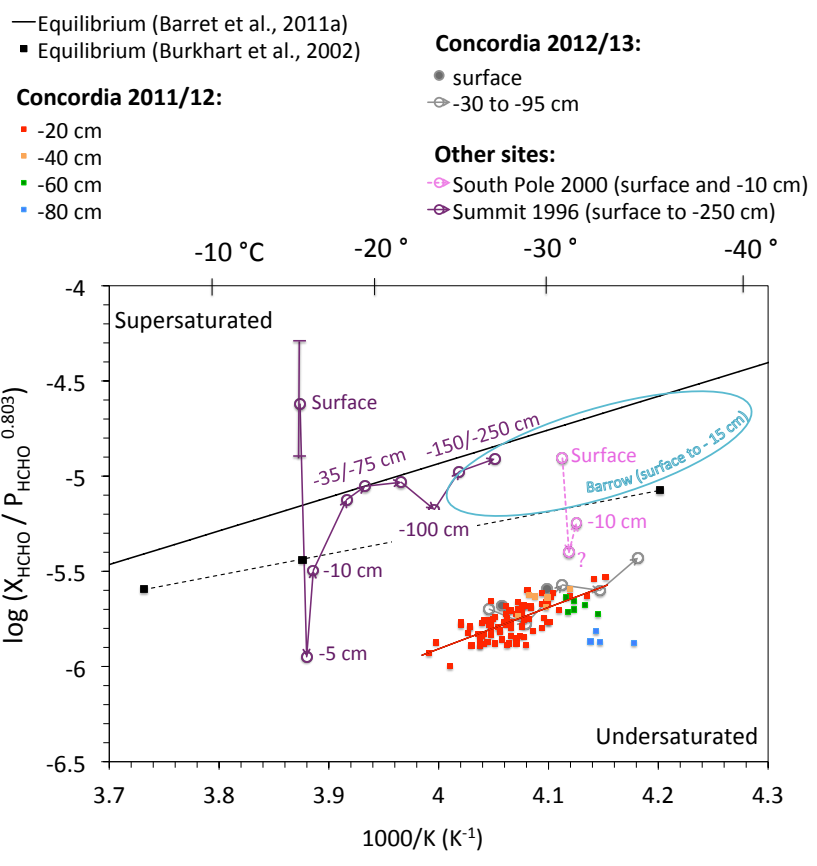

Figure 7. Arrhenius plot of the partitioning coefficient $K(T)$ for $\mathrm{HCHO}$ in firn air and snow of Concordia, South Pole, Summit, and Barrow versus $T^{-1}$. The thermodynamic equilibrium as estimated by Barret et al. (2011a) is shown as a black line. Barrow data, which use ambient air and not firn air measurements, are situated in the blue ellipse (Barret et al., 2011b). See discussion in text. Summit snow temperatures were calculated after Jun et al. (2002).

from further down are averaged over each of the six periods assigned in Fig. 2. The $X_{\mathrm{HCHO}}$ values used in calculations of $K(T)$ shown in Fig. 7 were derived from the mean snow-pit profile shown in Fig. 4.

As can be seen in Fig. 7, all data from Concordia indicate undersaturation of snow by a factor of 10 with respect to interstitial air. We notice that, whereas no significant difference appears between the two sets of data derived using firn air values collected in 2011/12 and 2012/13, data corresponding to $-70 \mathrm{~cm}$ in the $2012 / 13$ experiment show systematically lower $K(T)$ values. This latter difference is caused by the relatively high firn air mixing ratios seen at $70 \mathrm{~cm}$ depth in 2012/13 when compared to observations made just above and below (see Fig. 5). Thus we cannot exclude that the firn air sampling at this depth might have been somewhat overestimated, as it might happen due to the presence of an inhomogeneous structure of the snowpack (i.e., depth hoar and/or wind crusts), which might have brought air from above to the inlet.

At a first glance, Fig. 7 suggests that the strong undersaturation of snow at Concordia is very unique compared to the other sites. However, as already mentioned, the Barrow data that considered atmospheric (and not firn air) mixing ratios have clearly led to a significant underestimation of the degree of undersaturation of snow. Furthermore, the 
single point shown for South Pole in Fig. 7 is calculated with $3.2 \mathrm{ppbw}$ of bulk snow $\mathrm{HCHO}$ and a firn air value of $750 \mathrm{pptv}$ (Hutterli et al., 2004), which is, however, probably diluted by atmospheric air (Hutterli et al., 2004), leading to an underestimation of the degree of undersaturation of snow. Finally, at Summit, where snow and firn air profiles are well documented down to $2.5 \mathrm{~m}$ depth, a super-saturation was found at the surface, followed by striking undersaturation $5 \mathrm{~cm}$ below the surface. Further down, at the depth of the preceding winter, an almost perfect thermodynamic equilibrium was observed. Thereafter, except in the layer corresponding to the previous summer where snow is again undersaturated, most of the snow down to $2.5 \mathrm{~m}$ was close to the equilibrium. In conclusion, apart from Summit (with the noticeable exception of the snow located just below the surface), the polar snow appears often undersaturated with a particularly large depletion at Concordia. Note that, since a net $\mathrm{HCHO}$ flux out of the snow is detected during day and night at Concordia, the calculated undersaturation here needs to be considered as an upper value.

It is out of the scope of the present paper to investigate in detail the observed undersaturation of snow. At this stage we only assume (similar to Hutterli et al., 1999) that there is a process acting in summer that leads to a strong undersaturation of firn with respect to the thermodynamic air-ice equilibrium. This undersaturation is counteracted by (1) precipitation, fog and frost events which add supersaturated snow to the existing snowpack (Hutterli et al., 2004; Jacobi et al., 2002; Barret et al., 2011b) and (2) HCHO-rich snow layers further down originating from the preceding winter season (Hutterli et al., 1999, 2003). However, if the snow accumulation is extremely low, as at Dome $\mathrm{C}$, the preceding winter layer is still near the surface in summer, and supersaturated fresh snow is only seldom added to the snowpack. As a result, the regime of extreme undersaturation likely acts throughout the entire snowpack, confirmed by our measurements, at least in snow layers down to $1 \mathrm{~m}$ corresponding to ages of the last $\sim 10$ years. However, designing a more sophisticated modeling approach would require further data from Concordia obtained during winter in order to gain year-round information on $\mathrm{HCHO}$ in atmospheric air as well as in the interstitial air in the upper centimeters of the snowpack.

As already shown in Fig. 6, Fig. 7 suggests a temperaturedriven dependence of the firn air-snow partitioning at Concordia. The slope of the linear regression obtained with data at $-20 \mathrm{~cm}$ in the Arrhenius law in Fig. 7 (2.18 with $R^{2}=0.5$ ), for which a large range of temperature is encountered, is quite similar (only $20 \%$ higher) to the one of the thermodynamic equilibrium calculated by Barret et al. (2011a).

\subsubsection{Possible photochemical HCHO production in the snowpack}

As discussed in the preceding section, the assumption that snow emissions are controlled by temperature-driven exchanges (Hutterli et al., 2003) seems to be confirmed for Concordia conditions. While different experiments conducted at Alert and Barrow (Canadian and Alaskan Arctic) have shown that $\mathrm{HCHO}$ emissions due to photolytic degradation of organic matter are present there (Barret et al., 2011b, and references therein), this photolytic $\mathrm{HCHO}$ production seems to be very limited at inland polar ice sheet sites such as Summit (Hutterli et al., 1999) and South Pole (e.g., $<20 \%$ at South Pole) (Hutterli et al., 2004). To check directly whether the conclusion drawn for South Pole remains correct for Concordia, shading experiments were performed in January 2012 (see Sect. 2.2). No impact of cutting incident UV radiation (wavelengths $<380 \mathrm{~nm}$ ) on $\mathrm{HCHO}$ firn air concentrations at $10 \mathrm{~cm}$ below the surface snow depth was detected. This absence of changes does not, however, mean that no photochemical degradation of organic matter takes place, since the photolytic degradation of $\mathrm{HCHO}$ is also reduced during shading. Assuming a mean $e$-folding depth of $15 \mathrm{~cm}$ between 350 and $450 \mathrm{~nm}$ as measured by France et al. (2011) at Concordia in summer, and considering the $\mathrm{HCHO}$ photolytic rate during the shading experiment $\left(J_{\mathrm{HCHO}-\mathrm{rad}}+J_{\mathrm{HCHO}-m o l}\right.$ of $1.7 \times 10^{-4} \mathrm{~s}^{-1}$ at 14:00 LT for instance), we calculate that the photochemical production from organic matter, which may have been compensated for by the photolytic $\mathrm{HCHO}$ destruction, would not contribute more than $15 \%$ of the HCHO mixing ratio at $10 \mathrm{~cm}$ depth $(500-600 \mathrm{pptv}$ during this experiment). Such a weak impact of the degradation of organic matter in $\mathrm{HCHO}$ at Concordia is not surprising considering the difference in recent values of dissolved organic carbon (DOC) measured at Concordia and Barrow. Indeed, while Legrand et al. (2013) reported a mean value of $20 \mathrm{ppbC}$ (parts per billion of carbon) in the upper $10 \mathrm{~cm}$ surface snow at Concordia, Dominé et al. (2011) reported for snow and diamond dust layers at Barrow DOC levels ranging between 100 and $400 \mathrm{ppbC}$.

\section{Estimates of $\mathrm{HCHO}$ snow emissions at Concordia}

\subsection{Estimation derived from vertical gradient of atmospheric concentrations}

HCHO snow emission fluxes (F-HCHO) were derived from mixing ratios measured at $1 \mathrm{~cm}$ and $1 \mathrm{~m}$ above the snow surface using the integrated flux gradient method (e.g., Lenschow, 1995) detailed by Frey et al. (2015). In brief, the turbulent flux F-HCHO in the surface layer is parameterized according to the Monin-Obukhov similarity theory (MOST). For each 30 min, a mean $\mathrm{HCHO}$ gradient was calculated from 
the 15 min averaged mixing ratios successively observed at $1 \mathrm{~m}$ and $1 \mathrm{~cm}$.

As discussed in Frey et al. (2015), MOST requires that mixing ratios at $1 \mathrm{~m}$ and $1 \mathrm{~cm}$ be significantly different. Therefore, $30 \mathrm{~min}$ vertical gradients that were smaller than their respective $1 \sigma$ standard error, determined by error propagation of the $1 \sigma$ standard variability in $\mathrm{HCHO}$ mixing ratios, were not included in the calculations. In this way, from 14 to 18 December, 77 values of a total of 114 were considered, and 152 of 200 from 18 to 29 December. Note, however, that $90 \%$ of the considered values of the vertical gradient stay below the mean detection limit of ( $27 \pm 9$ pptv) calculated for the 14 to 28 December period (see Fig. 1b). In addition, the application of MOST also requires that the upper inlet height $(1 \mathrm{~m})$ is situated in the surface layer, i.e., below a height corresponding to $10 \%$ of the PBL height. If applied, this condition eliminates most of the nighttime data since the simulated PBL heights are as low as $10 \mathrm{~m}$ or less in $80 \%$ of cases between 21:00 and 05:00 LT over the 14 to 28 December period. Though these data are more uncertain than the others, in Fig. 3 we decided to still show fluxes calculated between 21:00 and 05:00 LT (grey area), even when this second condition for the applicability of the MOST model is not reached. As can be seen in Fig. 3, the arithmetic mean and median HCHO snow emission fluxes remain in fairly good agreement, reflecting the absence of 30 min data outliers.

Daily average F-HCHO values of $-0.36 \pm 1.6 \times 10^{12}$ molecules $\mathrm{m}^{-2} \mathrm{~s}^{-1}$ and of $2.7 \pm 2.7$ $\times 10^{12}$ molecules $\mathrm{m}^{-2} \mathrm{~s}^{-1}$ were calculated for the period between 14 and 18 December and 19 and 28 December, respectively. Whereas it is quasi-null over the first period, the calculated snow flux becomes positive in the period from 19 to 28 December. Whereas no systematic change over the course of the day can be detected during the first period, a maximum during the day $\left(\sim 4 \times 10^{12}\right.$ molecules $\mathrm{m}^{-2} \mathrm{~s}^{-1}$ from $08: 00$ to 17:00 LT compared to $1 \times 10^{12}$ molecules $\mathrm{m}^{-2} \mathrm{~s}^{-1}$ from 20:00 and 04:00 LT) was noticeable during the second half of December. Note that this increase in F-HCHO during the day results not only from the observed enhancement of the vertical gradient between $1 \mathrm{~cm}$ and $1 \mathrm{~m}$ (16 pptv from 08:00 to 17:00 LT compared to -6 pptv from 20:00 and 04:00 LT) but also from the increase in the friction velocity at that time of the day (Gallée et al., 2015). Both the increase in daily mean F-HCHO values from prior to after 18 December and the appearance of a diurnal maximum after 19 December are consistent with an increase in the snow air flux with enhanced temperatures as discussed in Sect. 4.3.1.

\subsection{Estimations derived from interstitial firn air measurements}

In view of the limited time period of available measurements and of the high uncertainty in the HCHO snow flux values derived from the relatively weak vertical $\mathrm{HCHO}$ gradients between $1 \mathrm{~cm}$ and $1 \mathrm{~m}$ (see Sect. 5.1), we also attempt to estimate HCHO snow fluxes on the basis of HCHO gradients observed between the interstitial air and the atmosphere. One advantage of this approach lies in the fact that the transport of $\mathrm{HCHO}$ in firn air is slower than that in the free atmosphere, leading to firn-atmosphere gradients that would largely exceed the detection limit of HCHO measurements.

In order to estimate firn air-atmosphere snow fluxes, Fick's law can be applied using measured concentration gradients between firn air and the atmosphere and the effective diffusion coefficient $\left(D_{\text {eff }}\right)$ in the open pore space. Since the turbulent diffusion in air above the snow is much larger than the diffusivity in firn air, the main concentration gradient will be in firn. Since HCHO air measurements made in 2011/12 (see Fig. 3) indicate a vertical gradient of only a few pptv, the use of mixing ratios on the MT inlet at $\sim 2 \mathrm{~m}$ as representative of HCHO level just above the surface is warranted.

Vertical transport in firn air of the top centimeters of the snowpack will depend on the molecular diffusion but can be significantly increased at high wind speed due to forced ventilation (Albert and Schultz, 2002). Following Schwander (1989), an effective molecular diffusion in firn ( $D_{\text {eff }}$ ) close to $1.3 \times 10^{-5} \mathrm{~m}^{2} \mathrm{~s}^{-1}$ is calculated for conditions at Concordia (at $650 \mathrm{mbar}, 244 \mathrm{~K}$, and a snow density of $0.35 \mathrm{~g} \mathrm{~cm}^{-3}$ ). Previous studies dealing with firn airatmosphere gradients in Antarctica (Hutterli et al., 2004; Frey et al., 2005) have assumed that, with wind speed lower than $5 \mathrm{~m} \mathrm{~s}^{-1}$, the wind pumping should have no significant influence with respect to molecular diffusion on motion in firn. However, more recently Seok et al. (2009) found an anticorrelation between wind speed and $\mathrm{CO}_{2}$ firn air gradients in the winter snowpack at a subalpine site in Colorado even at low wind speeds (a decrease by $50 \%$ of the gradient when wind speed increases from 0 to $3 \mathrm{~m} \mathrm{~s}^{-1}$ ). Therefore, we examine the dependence of the $\mathrm{HCHO}$ gradients between $-20 \mathrm{~cm}$ and the atmosphere at Concordia with air temperature and wind speed data. The multi-regression of HCHO gradients $\left(R^{2}=0.5\right)$ suggests a $\sim 50$ pptv decrease in the $\mathrm{HCHO}$ gradient when the wind speed reaches $5 \mathrm{~m} \mathrm{~s}^{-1}$, which can constitute up to $\sim 10 \%$ of $\mathrm{HCHO}$ gradients during certain time periods. Therefore, this effect of forced ventilation was considered in the HCHO flux reported below.

The approach used here to estimate the fluxes assumes a constant diffusivity coefficient and thus a linear change in mixing ratios between the two measurement levels. As discussed in Sect. 4, HCHO firn air levels are expected to reach a maximum in the uppermost $10 \mathrm{~cm}$ of the snowpack, and therefore the use of firn air data at $-20 \mathrm{~cm}$ would significantly underestimate the calculated $\mathrm{HCHO}$ fluxes. Therefore, an attempt was made to estimate $\mathrm{HCHO}$ mixing ratios in firn air near the surface by using the overall observed partitioning between snow and firn air observed at $-20 \mathrm{~cm}$ (Fig. 7) as a function of temperature, and the mean snow pit content measured between 4 and $10 \mathrm{~cm}$ (means of 0.80 and $0.94 \mathrm{ppb}$ ). The daily course of the firn temperature at $7 \mathrm{~cm}$ below the 
surface was taken as the mean of air and snow (at $20 \mathrm{~cm}$ below the surface) temperatures.

Figure 6 shows results obtained over two periods of the 2012/13 experiment, during which different mean air temperatures were encountered. It can be seen that $\mathrm{HCHO}$ levels at $-7 \mathrm{~cm}$ are clearly enhanced (up to $240 \mathrm{pptv}$ ) compared to $\mathrm{HCHO}$ levels measured at $-20 \mathrm{~cm}$ during the day, but are similar to the latter ones at night. Following calculations described above, mean $\mathrm{HCHO}$ fluxes out of the snow of $2.6 \pm 0.8 \times 10^{12}$ molecules $\mathrm{m}^{-2} \mathrm{~s}^{-1}$ and $1.8 \pm 0.7 \times 10^{12}$ molecules $\mathrm{m}^{-2} \mathrm{~s}^{-1}$ are calculated for the two periods during which mean air temperatures of -27.4 and $-31.3^{\circ} \mathrm{C}$ prevailed, respectively. Note that a significantly lower value $\left(0.65 \times 10^{12}\right.$ molecules $\left.\mathrm{m}^{-2} \mathrm{~s}^{-1}\right)$ is calculated for the end of January, when mean air temperatures dropped to $-37.5^{\circ} \mathrm{C}$.

Applying this approach to the December 2011 campaign over the periods of 14 to 18 December (mean air temperature of $-35^{\circ} \mathrm{C}$ ) and 19 to $28 \mathrm{De}$ cember (mean air temperature of $-29^{\circ} \mathrm{C}$ ) $\mathrm{HCHO}$ fluxes of $0.85 \pm 0.36 \times 10^{12}$ molecules $\mathrm{m}^{-2} \mathrm{~s}^{-1}$ and $2.15 \pm 0.93 \times 10^{12}$ molecules $\mathrm{m}^{-2} \mathrm{~s}^{-1}$ are estimated, which is (given the uncertainties of $\pm 3 \mathrm{~cm}$ in snow depth and of 0.08 ppbw in bulk snow HCHO) in good agreement with the corresponding flux estimates $\left(-0.36 \pm 1.6 \times 10^{12}\right.$ molecules $\mathrm{m}^{-2} \mathrm{~s}^{-1}$ from 14 to $18 \mathrm{De}-$ cember and $2.7 \pm 2.7 \times 10^{12}$ molecules $\mathrm{m}^{-2} \mathrm{~s}^{-1}$ from 19 to 28 December) made in Sect. 5.1 on the basis of atmospheric vertical gradients.

From the bulk snow content and an empirical partitioning between firn and in the snowpack, Hutterli et al. (2002) estimated a summer HCHO snow flux of $\sim 0.2 \times 10^{12}$ molecules $\mathrm{m}^{-2} \mathrm{~s}^{-1}$ at Concordia, which is 10 times lower than is derived from atmospheric and firn air measurements made in our study. Since calculations of Hutterli et al. (2002) are based on a thermodynamic equilibrium, it is very likely that a large part of the difference comes from the large undersaturation of snow with respect to interstitial air as observed at Concordia (Sect. 4.3.1).

\section{Sources and sinks controlling the atmospheric budget of $\mathrm{HCHO}$ at Concordia}

The importance of local gas-phase photochemical productions and snow emissions on the atmospheric $\mathrm{HCHO}$ mixing ratios observed at $1 \mathrm{~m}$ above the snow surface at Concordia in summer were investigated with 1-D model simulations. We performed calculations only for days with clearsky conditions (see Sect. 2.4). Whereas NO measurements started at the end of November 2011, those of $\mathrm{OH}$ and $\mathrm{RO}_{2}$ are only available after 19 December, and therefore we focus on the period from 19 to 28 December. The model was run each hour to simulate the daily cycle of $\mathrm{HCHO}$ mixing ratios. $\mathrm{OH}, \mathrm{HO}_{2}$ (estimated from $\mathrm{RO}_{2}$ measurements, Kukui
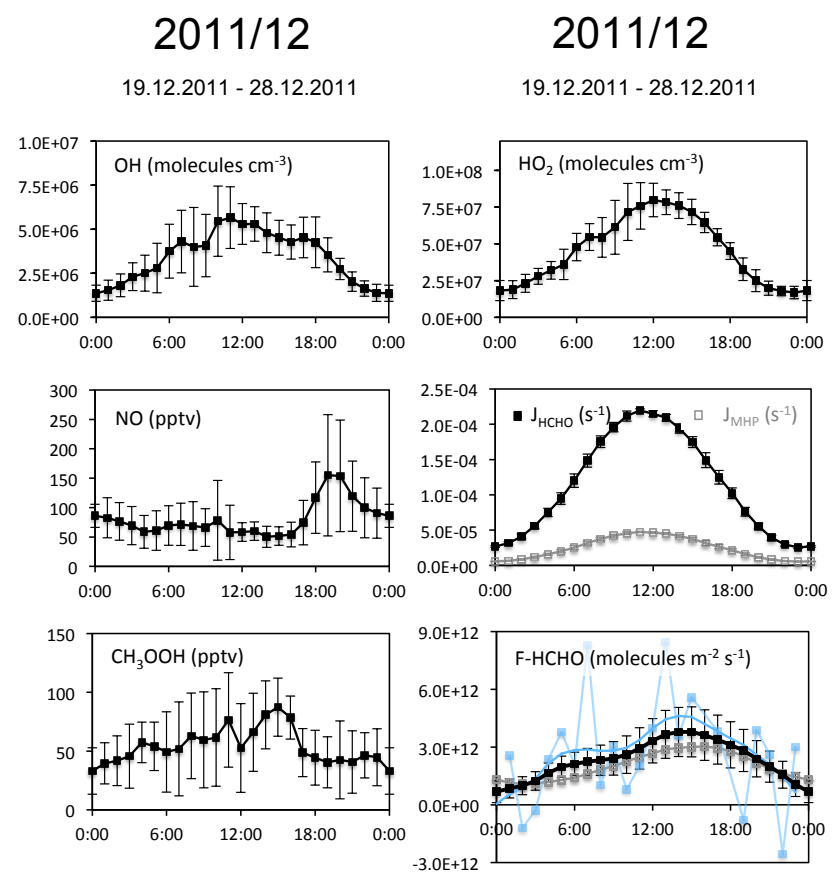

Figure 8. Diurnal cycles (hours are LT) of key input parameters used in 1-D simulations discussed in Sect. 6. $J_{\mathrm{HCHO}}$ denotes the sum of $J_{\mathrm{HCHO}-\mathrm{mol}}$ and $J_{\mathrm{HCHO}-\text { rad }}$ (see Table 1 ). HCHO fluxes (F$\mathrm{HCHO}$ ) used in the model were taken as the mean (black dots) of F$\mathrm{HCHO}$ derived from atmospheric $\mathrm{HCHO}$ gradients (blue dots) and from those derived from firn air atmosphere gradients (grey dots). Vertical bars refer to daily variability and to the uncertainty in calculations in the case of $\mathrm{F}-\mathrm{HCHO}$. $\mathrm{OH}$ and $\mathrm{HO}_{2}$ data are from Kukui et al. (2014), and those of NO are from Frey et al. (2015).

et al., 2014), NO, photolytic rates (see Sect. 2.2), and snow emission rates (see Sect. 5) were constrained by measurements. Their mean diurnal cycles are summarized in Fig. 8 together with that of measured MHP. A $\mathrm{CH}_{4}$ mixing ratio of $1758 \mathrm{ppbv}$ was used as recorded in December 2011 at the Syowa Antarctic station $\left(69^{\circ} \mathrm{S}\right)$. The HCHO snow emission fluxes considered in the model (hereafter denoted net HCHO snow flux) were calculated as the average of F-HCHO values derived from atmospheric HCHO gradients (Sect. 5.1) and of those derived from firn air-atmosphere gradients (Sect. 5.2).

\subsection{Gas-phase photochemical sources and sinks of HCHO}

In a first step, simulations of the gas-phase photochemistry only consider the $\mathrm{CH}_{4}$ oxidation by $\mathrm{OH}$ together with the two major sinks of HCHO, namely the photolysis (Reactions 11 and 12, Table 1) and the $\mathrm{OH}$ reaction (Reaction 9, Table 1). Hereby the initial $\mathrm{OH}$ attack leads to the formation of the methyl peroxy $\left(\mathrm{CH}_{3} \mathrm{O}_{2}\right)$ radical, which can react with $\mathrm{NO}$ to form $\mathrm{CH}_{3} \mathrm{O}$, which is then rapidly converted to $\mathrm{HCHO}$ with $\mathrm{O}_{2}$ (Reactions 1 to 3, Table 1). This reaction sequence is the dominant pathway under high-NO conditions as encountered 
at Concordia, whereas at low NO levels it would compete with Reactions (4) to (6) (Table 1). Simulations indicate that this methane oxidation pathway leads to steady-state mixing ratios of 56 and $91 \mathrm{pptv}$ at noon and midnight, respectively (Fig. 9a).

MHP can form $\mathrm{HCHO}, \mathrm{CH}_{3} \mathrm{O}$, or $\mathrm{CH}_{3} \mathrm{O}_{2}$ (Reactions 7, 8, and 10; Table 1). Since MHP measurements are available, the MHP contribution to the production of $\mathrm{HCHO}$ was examined separately from the $\mathrm{CH}_{4}$ oxidation pathway with $\mathrm{OH}$ and $\mathrm{NO}$ (Reactions 1 to 6, 9, 11, and 12; Table 1). As can be seen in Fig. 8, a daily mean MHP mixing ratio of $\sim 50$ pptv was observed at Concordia, which is nearly one half of the one reported by Frey et al. (2005) for South Pole. On the other hand, our model simulates a MHP mixing ratio of $20 \mathrm{pptv}$, suggesting that the MHP budget at Concordia consists of at least $\sim 40 \% \mathrm{CH}_{4}$ oxidation. Using observed MHP mixing ratios we calculate that $\sim 15 \mathrm{pptv}$ of $\mathrm{HCHO}$ is linked to the MHP breakdown (Fig. 9). Thus the MHP pathway accounts for $17 \%$ of the total $\mathrm{HCHO}$ production originating from the $\mathrm{CH}_{4}$ oxidation at Concordia. That is virtually the same as what was obtained at DDU (Preunkert et al., 2013), but only half of the corresponding value (i.e., 36\%) observed in the marine boundary layer (Wagner et al., 2002). As already concluded by Preunkert et al. (2013), this is due to the high level of $\mathrm{NO}$, which strengthens the $\mathrm{OH} / \mathrm{NO}$ methane oxidation pathway (Reaction 2) with respect to the $\mathrm{HO}_{2}$ and MHP pathway (Reaction 6).

On the basis of DOAS measurements made at Concordia, Frey et al. (2015) estimated that 2 to 3 pptv of $\mathrm{BrO}$ is present near the surface. Assuming a daily mean value of $2.5 \mathrm{pptv}$ of $\mathrm{BrO}$, we estimated the $\mathrm{Br}$ level to be of $0.43 \mathrm{pptv}$ from steady state calculations considering the $\mathrm{BrO}$ photolysis and the $\mathrm{Br}$ reaction with $\mathrm{O}_{3}$. Using these values and considering Reactions (13)-(15) of Table 1, we found that the $\mathrm{Br}$ chemistry represents a net $\mathrm{HCHO}$ loss that remains limited to -3 to -10 pptv from noon to midnight (Fig. 9b).

As can be seen in Fig. 8a, the simulated HCHO daily cycle resulting from the overall gas-phase chemistry accounts for 70 and 95 pptv (i.e., 65 and $68 \%$ of the observed $\mathrm{HCHO}$ level) at noon and at midnight, respectively. Such a large contribution of the local gas-phase chemistry was also found for South Pole, where oxidants are of similar abundance compared to Concordia: with a constant contribution of $2 \times 10^{6}$ molecules $\mathrm{cm}^{-3}$ of $\mathrm{OH}$ and $88 \mathrm{pptv}$ of NO (Eisele et al., 2008), $\sim 70 \%$ of the observed 110 pptv of $\mathrm{HCHO}$ was explained by the gas-phase chemistry (Hutterli et al., 2004) at South Pole.

\subsection{The impact of snow emissions on the HCHO budget}

As mentioned in Sect. 3 (see also Fig. 9a), the diurnal HCHO cycle observed over the period from 19 to 28 December 2011 is characterized by a daytime minimum with amplitude reaching 30 pptv. The simulated diurnal cycle related to the gas-phase chemistry reproduces a similar diurnal
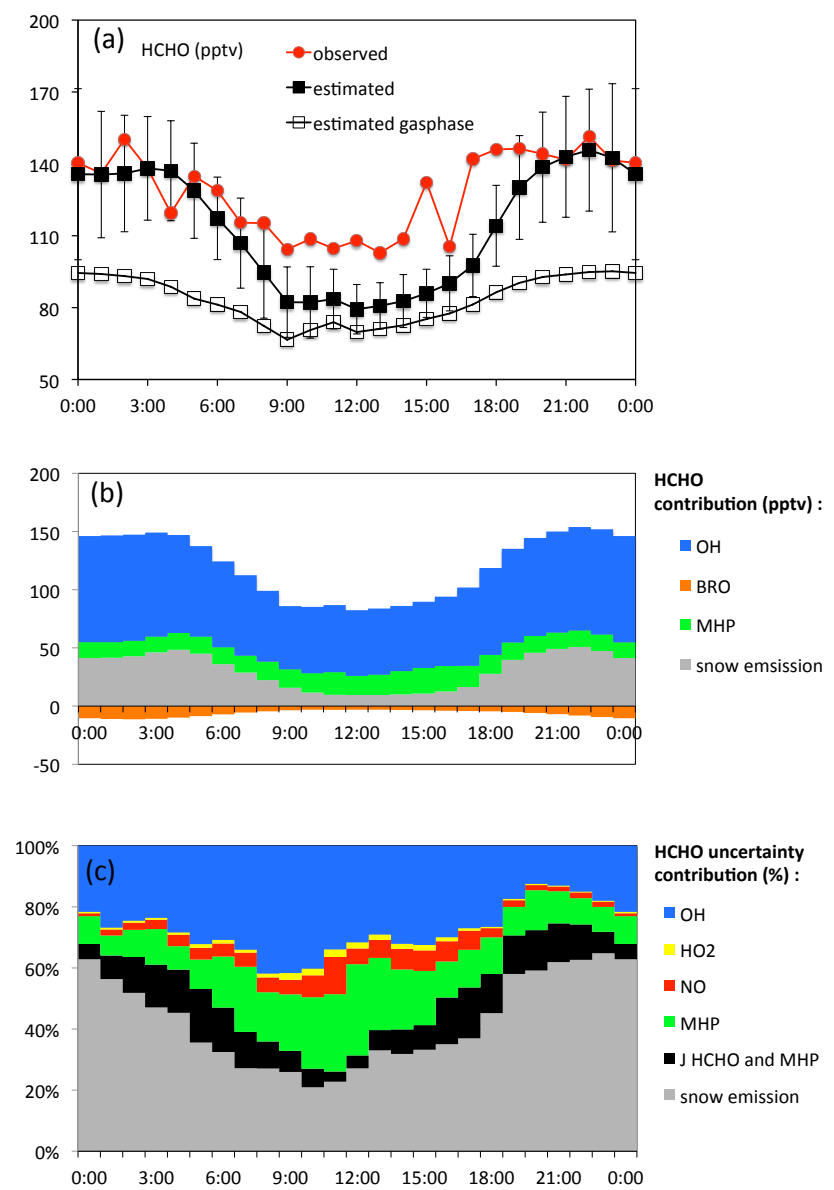

Figure 9. Diurnal cycles (hours are LT) for the period from 19 to 28 December 2011 of (a) HCHO simulated (squares) and observed (red circles) mixing ratios; grey open squares refer to values simulated when only the gas-phase chemistry is considered, whereas solid black squares refer to values simulated when both gas-phase chemistry and snow emissions are considered (see Sect. 6). The vertical bars shown on simulated values correspond to uncertainties related to the daily variability and calculation uncertainties in parameters shown in Fig. 8. (b) Simulated HCHO contributions of the different gas-phase mechanisms. (c) Contribution of the different uncertainties comprised in the vertical error bars in (a).

cycle but with a slightly weaker amplitude ( $\sim 30 \mathrm{pptv})$, and simulated $\mathrm{HCHO}$ mixing ratios underestimate observations by $\sim 40 \mathrm{pptv}$ at noon and $\sim 55 \mathrm{pptv}$ at night.

Considering the net HCHO snow flux (see Fig. 8) in addition to the above-discussed gas-phase chemistry, a daily mean $\mathrm{HCHO}$ mixing ratio of $112 \mathrm{pptv}$ is calculated, slightly lower compared to the observed $128 \mathrm{pptv}$. While simulations are in good agreement from 20:00 to 04:00 LT (Fig. 9a), they tend to underestimate observations by $30 \pm 9 \mathrm{pptv}$ from 09:00 to 15:00 LT. The simulated values indicate that $\mathrm{HCHO}$ snow emissions account for $\sim 30 \%$ of the observed $\mathrm{HCHO}$ mixing ratio at night and around $10 \%$ at noon. 
Note that, since the values of the HCHO snow emission rates are based on in situ measurements, they represent the net HCHO flux that also includes the effect of dry deposition. Therefore no dry deposition was considered in the simulations.

\subsection{Uncertainties in model calculations}

Simulations of gas-phase chemistry plus snow emissions indicate a better agreement with observations during the night than during the day. We investigated to what extent the uncertainties in simulations depend on the time of day and which parameters are responsible for that. The uncertainties in the preceding calculations include those linked to the kinetic rates of gas-phase calculations but are also related to the day-to-day variability in the hourly values used for $\mathrm{OH}$, $\mathrm{HO}_{2}$, NO, MHP, photolysis rates, and the uncertainty in the net $\mathrm{HCHO}$ snow emission flux as shown in Fig. 8. The uncertainty in the simulated turbulent transport also needs to be examined.

To evaluate the uncertainty linked to the kinetic rates of the main gas-phase $\mathrm{HCHO}$ production processes, a Monte Carlo study was performed in which all of the rate constants involved in methane oxidation (Reactions 1 to 9, Table 1) were modified simultaneously and independently of each other according to their probability distribution (see Preunkert et al., 2013, and Wagner et al., 2002, for further details). Including 1000 model runs, the uncertainty $( \pm 1 \sigma)$ in calculations related to the kinetic rates is close to $\pm 10 \mathrm{pptv}$ (i.e., $10 \%$ of calculated values) under daily mean Concordia summer conditions.

A Monte Carlo study was also applied to evaluate uncertainties resulting from the daily variability in $\mathrm{OH}, \mathrm{HO}_{2}, \mathrm{NO}$, MHP, photolysis rates, and the calculated uncertainty in the $\mathrm{HCHO}$ net snow emission. The overall $\mathrm{HCHO}$ error derived from this Monte Carlo study reaches \pm 13 pptv from 08:00 to $18: 00 \mathrm{LT}$ (mean simulated value of $88 \mathrm{pptv}$ ) and $\pm 26 \mathrm{pptv}$ from 20:00 to 04:00 LT (mean simulated value of $140 \mathrm{pptv}$ ). Although the $10 \%$ uncertainty in the $\mathrm{CH}_{4}$ oxidation constant rates is not included in errors shown in Fig. 9a, it can be seen that HCHO simulated values match observations during the night but underestimate them slightly during the day.

Figure $9 \mathrm{c}$ indicates the relative contribution of each parameter to the total uncertainty. It can be seen that, during the day (from 08:00 to 18:00 LT), the main uncertainty is related to the variability in $\mathrm{OH}$, the uncertainty in the net $\mathrm{HCHO}$ snow flux, and the strong daily variability in MHP, accounting for 33, 31, and 19\%, respectively. During the night (from 20:00 to $04: 00 \mathrm{LT}), 57 \%$ of the uncertainty is related to the net snow flux uncertainties and $20 \%$ from the variability in $\mathrm{OH}$. Note that the variability in NO plays no significant role on the uncertainty in simulated $\mathrm{HCHO}$ values, likely due to the excess of NO prevailing at Concordia, which ensures a minor influence of peroxy radical self-reactions compared to the reaction with NO (Reactions 2, 4, and 5; Table 1).
Finally, the influence of the strength and the height of the simulated turbulent transport was tested by increasing and decreasing $K_{z}$ values and the height of the vertical model levels by $30 \%$ - variations as typically encountered with MAR simulations for $K_{z}$ values and the estimated PBL height even under clear-sky conditions (Gallée et al., 2015). In brief, a successive decrease of $K_{z}$ values and vertical level heights by a factor of 0.7 increases calculated $\mathrm{HCHO}$ mixing ratios by $\sim 10$ and 20 pptv at midnight, respectively, while at noon the increase is limited to $\sim 3$ and $6 \mathrm{pptv}$, respectively. Similarly, a successive increase of $K_{z}$ values and vertical level heights by a factor of 1.3 decreases calculated $\mathrm{HCHO}$ mixing ratios by $\sim 7$ and 12 pptv at midnight, respectively, while at noon the decrease is only $\sim 2$ and $1.5 \mathrm{pptv}$, respectively. As for uncertainties related to $\mathrm{HCHO}$ net snow emission fluxes (Fig. 9c), higher uncertainties are encountered during the night due to the very low $K_{z}$ values and a very shallow mixing height prevailing at Concordia at that time, making atmospheric $\mathrm{HCHO}$ mixing ratios sensitive to any change in the snow emissions and the vertical transport. As a result, even when only clearsky conditions were considered in the calculations, uncertainties in the strength and the height of the simulated turbulent transport might increase the uncertainties in our $\mathrm{HCHO}$ calculations by at least 10 to $15 \%$.

When considering all above-discussed uncertainties, atmospheric HCHO mixing ratios of $89 \pm 22 \mathrm{pptv}$ for 08:00 to 18:00 LT and 140 $\pm 40 \mathrm{pptv}$ for 20:00 to 04:00 LT are calculated. These values are consistent with observations (i.e., $116 \pm 16 \mathrm{pptv}$ from 08:00 to $18: 00 \mathrm{LT}$ and $140 \pm 10 \mathrm{pptv}$ 20:00 to 04:00 LT), suggesting that no relevant $\mathrm{HCHO}$ source or sink has been missed in our estimation.

Previous 1-D HCHO simulations were made assuming that near-surface observed levels of $\mathrm{NO}$ and $\mathrm{HO}_{x}$ are constant within the whole PBL. Given the photochemical lifetime of $\mathrm{HCHO}$ (close to $1 \mathrm{~h}$ at noon and $7 \mathrm{~h}$ at night), we may expect a rather homogeneous distribution of $\mathrm{HCHO}$ within the PBL and the simulated $\mathrm{HCHO}$ value at $1 \mathrm{~m}$ would depend on the total production acting within the PBL. Therefore, the calculated $\mathrm{HCHO}$ value at $1 \mathrm{~m}$ depends on the vertical gradient of $\mathrm{HO}_{x}$ and NO. As detailed by Frey et al. (2015), a few vertical profiles of $\mathrm{NO}$ were obtained during balloon flights up to $100 \mathrm{~m}$. It appears that, during daytime, the lower PBL is well mixed with quasi-unchanged NO mixing ratios between 2.5 and $100 \mathrm{~m}$. Concerning $\mathrm{OH}$ and $\mathrm{HO}_{2}$, for which no data are available above $3 \mathrm{~m}$, we may expect only little change with height, since the unchanged levels of NO cause the main source of $\mathrm{OH}$, namely the recycling of $\mathrm{RO}_{2}$ by $\mathrm{NO}$, which represents here more than half of the total $\mathrm{OH}$ production at noon (Kukui et al., 2014), to remain unchanged. The second half of the total $\mathrm{OH}$ production corresponds to primary productions from ozone and $\mathrm{H}_{2} \mathrm{O}_{2}$ (representing together $50 \%)$ and HONO (50\%, considering the bias in measurements of this species discussed in Legrand et al., 2014) (Kukui et al., 2014). Ozone vertical profiles were regularly done during the OPALE campaign, showing well-mixed lev- 
els within the lower $100 \mathrm{~m}$ during day and night. Given the atmospheric lifetime of $\mathrm{H}_{2} \mathrm{O}_{2}(9 \mathrm{~h}$ compared to photolysis at noon), we can expect an absence of vertical gradient for this species as well. In fact, a strong vertical gradient is expected only for HONO given the suspected importance of a surface snow source for this species and a lifetime of $5 \mathrm{~min}$ at noon (Legrand et al., 2014). Therefore, assuming an overestimation of HONO by a factor of 4 as discussed in Kukui et al. (2014), a limited vertical change in $\mathrm{HO}_{x}$ within the PBL is expected, and consequently the assumption of a similar $\mathrm{HCHO}$ photochemical production throughout the whole PBL is reasonable. Conversely, the consistency between $\mathrm{HCHO}$ observations and simulations, considering constant $\mathrm{HO}_{x}$ levels within the PBL, supports the conclusion of an overestimation of HONO measurements, as drawn independently by Legrand et al. (2014) and Kukui et al. (2014).

\section{Summary}

This first study of ambient air HCHO measurements at Concordia indicates typical summer mixing ratios of $130 \mathrm{pptv}$. Model simulations indicate that the net gas-phase production from methane oxidation accounts largely (66\%) for observed mixing ratios in relation to the observed high levels of $\mathrm{OH}$ and $\mathrm{NO}$ there in summer. $\mathrm{HCHO}$ measurements conducted in the three environmental compartments (ambient air, firn air, and snow) confirm that the snow at Concordia is a net source of $\mathrm{HCHO}$ in summer throughout day and night. Though a strong undersaturation of the snowpack with respect to interstitial air compared to the pure ice-air thermodynamic equilibrium is observed, no significant change in $\mathrm{HCHO}$ production was observed during shading experiments, suggesting that snow emissions are mainly controlled by temperature-driven exchanges rather than by photolytic degradation of organic matter. Snow emission fluxes estimated from vertical gradients between $1 \mathrm{~cm}$ and $1 \mathrm{~m}$ above the snow surface and between air just below and above the snow surface consistently suggest levels between 1 and $2 \times 10^{12}$ molecules $\mathrm{m}^{-2} \mathrm{~s}^{-1}$ at night and 3 to $5 \times 10^{12}$ molecules $\mathrm{m}^{-2} \mathrm{~s}^{-1}$ at noon. One-dimensional simulations considering these snow emissions and the gas-phase chemistry (mainly the methane oxidation) calculate a daily mean HCHO mixing ratio of 112 pptv, in good agreement with the observed $\sim 130$ pptv; however, they show an underestimate by 30 pptv at midday. Further field studies with particular emphasis on measurements in the three compartments in winter are necessary in order to gain a better understanding of the overall strong undersaturation of snow at the site.

Acknowledgements. The OPALE project was funded by the ANR (Agence National de Recherche) through contract ANR-09-BLAN0226. National financial support and field logistic supplies for the summer campaign were provided by the Institut Polaire FrançaisPaul Emile Victor (IPEV) through program nos. 414, 903, and
1011. The 2012-2014 snowpack air sampling experiments were funded by an award to D. Helmig and J. Savarino from the United States National Science Foundation Office of Polar Programs (NSF \#1142145). M. D. King was supported through NERC NE/F0004796/1 and NE/F010788 grants and NERC FSF grants 555.0608 and 584.0609. We thank PNRA for providing temperature and pressure data at Concordia. Thanks to Edward J. Dlugokencky and the World Data Centre for Greenhouse Gases for providing $\mathrm{CH}_{4}$ data from the Syowa station.

Edited by: T. Bartels-Rausch

\section{References}

Albert, M. R. and Shultz, E. F.: Snow and firn properties and air-snow transport processes at Summit, Greenland, Atmos. Environ., 36, 2789-2797, doi:10.1016/S1352-2310(02)00119-X, 2002.

Atkinson, R., Baulch, D. L., Cox, R. A., Crowley, J. N., Hampson, R. F., Hynes, R. G., Jenkin, M. E., Rossi, M. J., Troe, J., and IUPAC Subcommittee: Evaluated kinetic and photochemical data for atmospheric chemistry: Volume II - gas phase reactions of organic species, Atmos. Chem. Phys., 6, 3625-4055, doi:10.5194/acp-6-3625-2006, 2006.

Atkinson, R., Baulch, D. L., Cox, R. A., Crowley, J. N., Hampson, R. F., Hynes, R. G., Jenkin, M. E., Rossi, M. J., and Troe, J.: Evaluated kinetic and photochemical data for atmospheric chemistry: Volume III - gas phase reactions of inorganic halogens, Atmos. Chem. Phys., 7, 981-1191, doi:10.5194/acp-7-981-2007, 2007.

Atkinson, R., Baulch, D. L., Cox, R. A., Crowley, J. N., Hampson, R. F., Hynes, R. G., Jenkin, M. E., Rossi, M. J., Troe, J. and Wallington, T. J.: Evaluated kinetic and photochemical data for atmospheric chemistry: Volume IV - gas phase reactions of organic halogen species, Atmos. Chem. Phys., 8, 4141-4496, doi:10.5194/acp-8-4141-2008, 2008.

Barret, M., Houdier, S., and Domine, F.: Thermodynamics of the Formaldehyde-Water and Formaldehyde-Ice Systems for atmospheric implications, J. Phys. Chem. A, 115, 307-317, doi:10.1021/jp108907u, 2011a.

Barret, M., Domine, F., Houdier, S., Gallet, J.-C., Weibring, P., Walega, J., Fried, A., and Richter, D.: Formaldehyde in the Alaskan Arctic snowpack: Partitioning and physical processes involved in air-snow exchanges, J. Geophys. Res., 116, D00R03, doi:10.1029/2011JD016038, 2011b.

Beyersdorf, A. J., Blake, D. R., Swanson, A., Meinardi, S., Rowland, F. S., and Davis, D.: Abundances and variability of tropospheric volatile organic compounds at the South Pole and other Antarctic locations, Atmos. Environ., 44, 4565-4574, doi:10.1016/j.atmosenv.2010.08.025, 2010.

Bloss, W. J., Lee, J. D., Heard, D. E., Salmon, R. A., Bauguitte, S. J.-B., Roscoe, H. K., and Jones, A. E.: Observations of $\mathrm{OH}$ and $\mathrm{HO}_{2}$ radicals in coastal Antarctica, Atmos. Chem. Phys., 7 , 4171-4185, doi:10.5194/acp-7-4171-2007, 2007.

Burkhart, J. F., Hutterli, M. A., and Bales, R. C.: Partitioning of formaldehyde between air and ice at $-35^{\circ} \mathrm{C}$ to $-5^{\circ} \mathrm{C}$, Atmos. Environ., 36, 2157-2163, 2002.

Chen, G., Davis, D., Crawford, J., Hutterli, L. M., Huey, L. G., Slusher, D., Mauldin, L., Eisele, F., Tanner, D., Dibb, 
J., Buhr, M., McConnell, J., Lefer, B., Shetter, R., Blake, D., Song, C. H., Lombardi, K., and Arnoldy, J.: A reassessment of $\mathrm{HO}_{x}$ South Pole chemistry based on observations recorded during ISCAT 2000, Atmos. Environ., 38, 5451-5461, doi:16/j.atmosenv.2003.07.018, 2004.

Dasgupta, P. K., Dong, S., Hwang, H., Yang, H.-C., and Genfa, Z.: Continuous liquid-phase fluorometry coupled to a diffusion scrubber for the real-time determination of atmospheric formaldehyde, hydrogen peroxide and sulfur dioxide, Atmos. Environ., 22, 949-963, doi:10.1016/0004-6981(88)902739, 1988.

DeMore, W. B., Sander, S. P., Golden, D. M., Hampson, R. F., Kurylo, M. J., Howard, C. J., Ravishankara, A. R., Kolb, C. E., and Molina, M. J.: Chemical kinetics and photochemical data for use in stratospheric modeling, Evaluation, 12, JPL Publ., 97-4, 15 January, JPL: Pasadena, CA, 1997.

Dominé, F., Gallet, J.-C., Barret, M., Houdier, S., Voisin, D., Douglas, T. A., Blum, J. D., Beine, H. J., Anastasio, C., and Bréon, F.-M.: The specific surface area and chemical composition of diamond dust near Barrow, Alaska, J. Geophys. Res., 116, D00R06, doi:10.1029/2011JD016162, 2011.

Eisele, F., Davis, D. D., Helmig, D., Oltmans, S. J., Neff, W., Huey, G., Tanner, D., Chen, G., Crawford, J., Arimoto, R., Buhr, M., Mauldin, L., Hutterli, M., Dibb, J., Blake, D., Brooks, S. B., Johnson, B., Roberts, J. M., Wang, Y. H., Tan, D., and Flocke, F.: Antarctic Tropospheric Chemistry Investigation (ANTCI) 2003 overview, Atmos. Environ., 42, 2749-2761, 2008.

France, J. L., King, M. D., Frey, M. M., Erbland, J., Picard, G., Preunkert, S., MacArthur, A., and Savarino, J.: Snow optical properties at Dome C (Concordia), Antarctica; implications for snow emissions and snow chemistry of reactive nitrogen, Atmos. Chem. Phys., 11, 9787-9801, doi:10.5194/acp-11-97872011, 2011.

Frey, M. M., Steward, R. W., McConnell, J. R., and Bales, R. C.: Atmospheric hydroperoxides in West Antarctica: Links to stratospheric ozone atmospheric oxidation capacity, J. Geophys. Res., 110, D23301, doi:10.1029/2005JD006110, 2005.

Frey, M. M., Brough, N., France, J. L., Anderson, P. S., Traulle, O., King, M. D., Jones, A. E., Wolff, E. W., and Savarino, J.: The diurnal variability of atmospheric nitrogen oxides (NO and $\mathrm{NO}_{2}$ ) above the Antarctic Plateau driven by atmospheric stability and snow emissions, Atmos. Chem. Phys., 13, 3045-3062, doi:10.5194/acp-13-3045-2013, 2013.

Frey, M. M., Roscoe, H. K., Kukui, A., Savarino, J., France, J. L., King, M. D., Legrand, M., and Preunkert, S.: Atmospheric nitrogen oxides ( $\mathrm{NO}$ and $\mathrm{NO}_{2}$ ) at Dome $\mathrm{C}$, East Antarctica, during the OPALE campaign, Atmos. Chem. Phys. Discuss., 14, 3128131317, doi:10.5194/acpd-14-31281-2014, 2014.

Gallée, H. and Gorodetskaya, I.: Validation of a limited area model over Dome C, Antarctic 29 Plateau, during winter, 34, 6172, Clim. Dynam., 34, 61-72, doi:10.1007/s00382-008-0499-y, 2008.

Gallée, H., Preunkert, S., Argentini, S., Frey, M. M., Genthon, C., Jourdain, B., Pietroni, I., Casasanta, G., Barral, H., Vignon, E., Amory, C., and Legrand, M.: Characterization of the boundary layer at Dome C (East Antarctica) during the OPALE summer campaign, Atmos. Chem. Phys., 15, 62256236, doi:10.5194/acp-15-6225-2015, 2015.
Helmig, D., Bocqueta, F., Cohena, L., and Oltmans, S. J.: Ozone uptake to the polar snowpack at Summit, Greenland, Atmos. Environ., 41, 5061-5076, doi:10.1016/j.atmosenv.2006.06.064, 2007.

Hutterli, M. A., Rothlisberger, R., and Bales, R. C.: Atmosphere-to-snow-to-firn transfer studies of $\mathrm{HCHO}$ at Summit, Greenland, Geophys. Res. Lett., 26, 1691-1694, doi:10.1029/1999GL900327, 1999.

Hutterli, M. A., Bales, R. C., McConnell, J. R., and Stewart, R. W.: HCHO in Antarctic snow: Preservation in ice cores and air-snow exchange, Geophys. Res. Lett., 29, 1235, doi:10.1029/2001GL014256, 2002.

Hutterli, M. A., McConnell, J. R., Bales, R. C., and Stewart, R. W.: Sensitivity of hydrogen peroxide $\left(\mathrm{H}_{2} \mathrm{O}_{2}\right)$ and formaldehyde ( $\mathrm{HCHO}$ ) preservation in snow to changing environmental conditions: Implications for ice core records, J. Geophys. Res., 108, 4023, doi:10.1029/2002JD002528, 2003.

Hutterli, M. A., McConnell, J. R., Chen, G., Bales, R. C., Davis, D. D., and Lenschow, D. H.: Formaldehyde and hydrogen peroxide in air, snow and interstitial air at South Pole, Atmos. Environ., 38, 5439-5450, 2004.

Jacobi, H. W., Frey, M. M., Hutterli, M. A., Bales, R. C., Schrems, O., Cullen, N. J., Steffen, K., and Koehler, C.: Measurements of hydrogen peroxide and formaldehyde exchange between the atmosphere and surface snow at Summit, Greenland, Atmos. Environ., 36, 2619-2628, 2002.

Jun, L., Weili, W., and Zwally, H. J.: Interannual variations of shallow firn temperature at Greenland summit, Ann. Glaciol., 35, 368-370, doi:10.3189/172756402781816933, 2002.

Kukui, A., Legrand, M., Ancellet, G., Gros, V., Bekki, S., SardaEstève, R., Loisil, R., and Preunkert, S.: Measurements of $\mathrm{OH}$ and $\mathrm{RO}_{2}$ radicals at the coastal Antarctic site of Dumont d'Urville (East Antarctica) in summer, J. Geophys. Res., 117, D12310, doi:10.1029/2012JD017614, 2012.

Kukui, A., Legrand, M., Preunkert, S., Frey, M. M., Loisil, R., Gil Roca, J., Jourdain, B., King, M. D., France, J. L., and Ancellet, G.: Measurements of $\mathrm{OH}$ and $\mathrm{RO}_{2}$ radicals at Dome C, East Antarctica, Atmos. Chem. Phys., 14, 12373-12392, doi:10.5194/acp-14-12373-2014, 2014.

Legrand, M., Preunkert, S., Schock, M., Cerqueira, M., KasperGiebl, A., Afonso, J., Pio, C., Gelencsér, A., and DombrowskiEtchevers, I.: Major 20th century changes of carbonaceous aerosol components (EC, WinOC, DOC, HULIS, carboxylic acids, and cellulose) derived from Alpine ice cores, J. Geophys. Res., 112, D23S11, doi:10.1029/2006JD008080, 2007.

Legrand, M., Preunkert, S., Jourdain, B., Legrand, M., Preunkert, S., Jourdain, B., Guilhermet, J., Faïn, X., Alekhina, I., and Petit, J. R.: Water-soluble organic carbon in snow and ice deposited at Alpine, Greenland, and Antarctic sites: a critical review of available data and their atmospheric relevance, Clim. Past, 9, 21952211, doi:10.5194/cp-9-2195-2013, 2013.

Legrand, M., Preunkert, S., Frey, M., Bartels-Rausch, Th., Kukui, A., King, M. D., Savarino, J., Kerbrat, M., and Jourdain, B.: Large mixing ratios of atmospheric nitrous acid (HONO) at Concordia (East Antarctic Plateau) in summer: a strong source from surface snow?, Atmos. Chem. Phys., 14, 9963-9976, doi:10.5194/acp-14-9963-2014, 2014.

Lenschow, D. H.: Micrometeorological techniques for measuring biosphere-atmosphere trace gas exchange, in: Biogenic Trace Gases: Measuring emissions from soil and water, edited by: Mat- 
son, P. A. and Harriss, R. C., 126-163, Blackwell Science, London, 1995.

Lowe, D. C. and Schmidt, U.: Formaldehyde (HCHO) measurements in the Nonurban Atmosphere, J. Geophys. Res., 88, 10844-10858, doi:198310.1029/JC088iC15p10844, 1983.

Michalowski, B. A., Francisco, J. S., Li, S.-M., Barrie, L. A., Bottenheim, J. W., and Shepson, P. B.: A computer model study of multiphase chemistry in the Arctic boundary layer during polar sunrise, J. Geophys. Res., 105, 15131-15145, 2000.

Preunkert, S., Jourdain, B., Legrand, M., Udisti, R., Becagli, S., and Cerri, O.: Seasonality of sulfur species (sulfate, methanesulfonate and dimethyl sulfur) in Antarctica: inland versus coastal regions, J. Geophys. Res., 113, D15302, doi:10.1029/2008JD009937, 2008.

Preunkert S., Ancellet, G., Legrand, M., Kukui, A., Kerbrat, M., Sarda-Estève, R., Gros, V., and Jourdain, B.: Oxidant Production over Antarctic Land and its Export (OPALE) project: An overview of the 2010-2011 summer campaign, J. Geophys. Res., 117, D15307, doi:10.1029/2011JD017145, 2012.

Preunkert, S., Legrand, M., Pépy, G., Gallée, H., Jones, A., and Jourdain, B.: The atmospheric HCHO budget at Dumont d'Urville (East Antarctica): Contribution of photochemical gasphase production versus snow emissions, J. Geophys. Res.Atmos., 118, 13319-13337, doi:10.1002/2013JD019864, 2013.

Riedel, K., Weller, R., and Schrems, O.: Variability of formaldehyde in the Antarctic troposphere, Phys. Chem. Chem. Phys., 1, 5523 5527, 1999.

Salmon, R. A., Bauguitte, S. J.-B., Bloss, W., Hutterli, M. A., Jones, A. E., Read, K., and Wolff, E. W.: Measurement and interpretation of gas phase formaldehyde concentrations obtained during the CHABLIS campaign in coastal Antarctica, Atmos. Chem. Phys., 8, 4085-4093, doi:10.5194/acp-8-4085-2008, 2008.
Schwander, J.: The transformation of snow to ice and the occlusion of gases, in: The Environmental Record in Glaciers and Ice Sheets, edited by: Oeschger, H. and Langway Jr., C. C., 53-67, John Wiley, New York, 1989.

Seinfeld, J. H. and Pandis, S. P.: Atmospheric Chemistry and Physics: From Air Pollution to Climate Change, 2nd Edn., 1232 pp., John Wiley, New Jersey, 2006.

Seok, B., Helmig, D., Williams, M. W., Liptzin, D., Chowanski, K., and Hueber, J.: An automated system for continuous measurements of trace gas fluxes through snow: an evaluation of the gas diffusion method at a subalpine forest site, Niwot Ridge, Colorado, Biogeochemistry, 113, p. 95, doi:10.1007/s10533-0099302-3, 2009.

Sumner, A. L. and Shepson, P. B.: Snowpack production of formaldehyde and its effect on the Arctic troposphere, Nature, 398, 230-233, doi:10.1038/18423, 1999.

Wagner, V., von Glasow, R., Fischer, H., and Crutzen, P. J.: Are $\mathrm{CH}_{2} \mathrm{O}$ measurements in the marine boundary layer suitable for testing the current understanding of $\mathrm{CH} 4$ photooxidation?: A model study, J. Geophys. Res., 107, ACH3.1-ACH3.14, doi:10.1029/2001JD000722, 2002.

Yang, J., Honrath, R. E., Peterson, M. C., Dibb, J. E., Sumner, A. L., Shepson, P. B., Frey, M., Jacobi, H.-W., Swanson, A., and Blake, N.: Impacts of snowpack emissions on deduced levels of $\mathrm{OH}$ and peroxy radicals at Summit, Greenland, Atmos. Environ. 36, 2523-2534, 2002. 